\title{
Dust impact on surface solar irradiance assessed with model simulations, satellite observations and ground-based measurements
}

\author{
Panagiotis G. Kosmopoulos $^{1,2}$, Stelios Kazadzis ${ }^{3}$, Michael Taylor ${ }^{2}$, Eleni Athanasopoulou ${ }^{1}$, Orestis Speyer ${ }^{1}$, \\ Panagiotis I. Raptis ${ }^{1,3}$, Eleni Marinou ${ }^{2,4}$, Emmanouil Proestakis ${ }^{4,5}$, Stavros Solomos ${ }^{4}$, Evangelos Gerasopoulos ${ }^{1,6}$, \\ Vassilis Amiridis $^{4}$, Alkiviadis Bais ${ }^{2}$, and Charalabos Kontoes ${ }^{4}$ \\ ${ }^{1}$ Institute for Environmental Research and Sustainable Development, National Observatory of Athens, Athens, Greece \\ ${ }^{2}$ Laboratory of Atmospheric Physics, Aristotle University of Thessaloniki, Thessaloniki, Greece \\ ${ }^{3}$ Physicalisch-Meteorologisches Observatorium Davos, World Radiation Center, Davos, Switzerland \\ ${ }^{4}$ Institute for Astronomy, Astrophysics, Space Applications and Remote Sensing, National Observatory of Athens, Athens, \\ Greece \\ ${ }^{5}$ Laboratory of Atmospheric Physics, Department of Physics, University of Patras, Patras, Greece \\ ${ }^{6}$ Navarino Environmental Observatory, Messenia, Greece \\ Correspondence to: Panagiotis G. Kosmopoulos (pkosmo@meteo.noa.gr)
}

Received: 20 March 2017 - Discussion started: 22 March 2017

Revised: 12 June 2017 - Accepted: 13 June 2017 - Published: 11 July 2017

\begin{abstract}
This study assesses the impact of dust on surface solar radiation focussing on an extreme dust event. For this purpose, we exploited the synergy of AERONET measurements and passive and active satellite remote sensing (MODIS and CALIPSO) observations, in conjunction with radiative transfer model (RTM) and chemical transport model (CTM) simulations and the 1-day forecasts from the Copernicus Atmosphere Monitoring Service (CAMS). The area of interest is the eastern Mediterranean where anomalously high aerosol loads were recorded between 30 January and 3 February 2015. The intensity of the event was extremely high, with aerosol optical depth (AOD) reaching 3.5, and optical/microphysical properties suggesting aged dust. RTM and CTM simulations were able to quantify the extent of dust impact on surface irradiances and reveal substantial reduction in solar energy exploitation capacity of PV and CSP installations under this high aerosol load. We found that such an extreme dust event can result in Global Horizontal Irradiance (GHI) attenuation by as much as 40 $50 \%$ and a much stronger Direct Normal Irradiance (DNI) decrease (80-90\%), while spectrally this attenuation is distributed to $37 \%$ in the UV region, $33 \%$ in the visible and around $30 \%$ in the infrared. CAMS forecasts provided a reliable available energy assessment (accuracy within $10 \%$ of that obtained from MODIS). Spatially, the dust plume re-
\end{abstract}

sulted in a zonally averaged reduction of GHI and DNI of the order of $150 \mathrm{~W} \mathrm{~m}^{-2}$ in southern Greece, and a mean increase of $20 \mathrm{~W} \mathrm{~m}^{-2}$ in the northern Greece as a result of lower AOD values combined with local atmospheric processes. This analysis of a real-world scenario contributes to the understanding and quantification of the impact range of high aerosol loads on solar energy and the potential for forecasting power generation failures at sunshine-privileged locations where solar power plants exist, are under construction or are being planned.

\section{Introduction}

Solar energy potential is sensitive to various atmospheric parameters. In addition to the solar zenith angle (SZA) as the key determining factor, cloud presence is another factor that attenuates solar radiation arriving at the earth's surface. For this, large photovoltaic (PV) installations are built where solar insolation is high and cloud-free sky conditions prevail for the largest part of the year. However, in the case of Europeansponsored installations, they are also significantly affected by mineral dust, mainly perimetrically of the western (e.g. the 160 MW Noor concentrated solar power (CSP) in Morocco) 
and eastern (e.g. the $150 \mathrm{MW}$ Kuraymat CSP in Egypt and the $130 \mathrm{MW}$ Ashalim CSP in Israel) Mediterranean.

The aerosol radiative effects over the eastern Mediterranean (EM) have been studied systematically in the last decade (e.g. Papadimas et al., 2012; Turnock et al., 2015; Lindfors et al., 2013). It is a semi-enclosed sea surrounded by continental area with discrete sources of aerosols and it is characterised by large direct radiative effects due to high and frequently dust loads, especially during spring (Kosmopoulos et al., 2008; Gkikas et al., 2012, 2013; Flaounas et al., 2015; Athanasopoulou et al., 2016). A recent climatology of global aerosol mixtures, derived from 7 years GOCART model simulations (Taylor et al., 2015), suggests that dust is the primary component of aerosol mixtures over the eastern Mediterranean. While the spatial extent of dust mixtures is fairly stable on the seasonal timescale, it is highly variable in time at the local scale. Desert dust plays an important role in the radiative forcing (RF), with an estimated top of atmosphere (TOA) RF in the range of -0.6 to $0.5 \mathrm{~W} \mathrm{~m}^{-2}$ (IPCC, 2013), and $-0.96 \mathrm{~W} \mathrm{~m}^{-2}$ at the ground (Tegen et al., 1996). Still, dust-induced RF is very uncertain in both magnitude and sign, driven by the chemical composition of mineral particles (Claquin et al., 1998), the wavelength dependence of their optical properties (e.g. single-scattering albedo, SSA, asymmetry factor) as well as the albedo of the underlying surface and the relative height between the dust layer and the clouds (Kaufman et al., 2001; Kinne and Pueschel, 2001; Pandithurai et al., 2008).

In the absence of clouds, dust is the main source of attenuation of the surface solar radiation (SSR), with the DNI being affected much more intensively than the GHI. Many studies focus on different approaches to quantify and estimate the impact of dust on the SSR (Dirnberger et al., 2015; Ishii et al., 2013; Lindfors et al., 2013; Allen et al., 2013; Qian et al., 2007; Papayiannis et al., 2005). In order to assess the impact of strong dust events on solar energy, a monthly climatology of aerosol optical depth (AOD) and spectrally integrated SSR, including the DNI and the GHI, was calculated with the radiative transfer model (RTM) libRadtran (Mayer and Kylling, 2005). LibRadtran contains a library of radiative transfer routines which, advantageously over other models (Emde and Mayer, 2007; Cahala et al., 2005; Marquart and Mayer, 2002), were originally designed to calculate spectral irradiance in the ultraviolet and visible spectral ranges. It is user friendly, since it allows for the definition of the RTM inputs with human-readable files, and finds applications in the simulation of instruments, calculation of the radiation budget of the earth and, as in this study, in the development of remote sensing techniques. The present study computes the direct effect of the extreme dust event on 1 February 2015 on the radiative energy budget using satellite and ground-based data as input to the RTM. The study area covers the eastern Mediterranean and, more specifically, the region of Greece. Dust cases in winter are rare but intense when they occur (Gerasopoulos et al., 2011; Kosmopoulos et al., 2011); thus the study of such an event is of great interest with respect to low incoming SSR and the typical winter meteorological conditions. In order to better understand this effect, we used data from different sources to perform a multi-model analysis of the intense incursion of Saharan dust into south-eastern Europe during the study period that began with a cyclogenesis to the north of Libya on 28 January 2015, peaked over the Mediterranean on 1 February 2015 and dissipated a couple of days later. The data synergy is provided by (i) RTM simulations from libRadtran, (ii) chemical transport model (CTM) simulations from COSMO-ART, (iii) satellite aerosol retrievals from the MODIS spectroradiometer, (iv) aerosol profiling from CALIPSO (Cloud-Aerosol Lidar and Infrared Pathfinder Satellite Observations), (v) aerosol retrievals provided by AERONET sun photometers and their inversion algorithm and, finally, (vi) aerosol product retrievals from the CAMS. We measure the attenuation of SSR during the course of the evolution of the dust outbreak and correlate it with the available data (e.g. CAMS against MODIS) to assess the relative impact of dust aerosol on solar power over the study area. The work is organised as follows: in Sect. 2 the measurements and models used are presented; then the results from the 3-D observation and ground-based dimension of the dust event evolution, together with the impacts on surface solar radiation are presented in Sect. 3; finally, the conclusions are provided in Sect. 4.

\section{Measurements and models}

\subsection{Measurements}

\subsubsection{MODIS and CALIPSO}

The MODerate resolution Imaging Spectroradiometer (MODIS) sensors are among the primary instruments on board the polar orbit sun-synchronous NASA satellites Terra and Aqua (Salomonson et al., 1989). MODIS sensors have provided retrievals of AOD at $550 \mathrm{~nm}$ since February 2000 and June 2002 for Terra and Aqua satellites respectively. The retrievals of MODIS sensors are established against different types of land surface, based on a pair of complementary algorithms, Dark Target (DT) and Deep Blue (DB). The DT algorithm is used over vegetated/dark land surfaces which are characterised by low reflectance and additionally over ocean, while the DB algorithm provides AOD retrievals over bright and arid land surfaces (Levy et al., 2013). The accuracy of Collection 6 (C6) MODIS DT algorithm is approximately equal to $\pm\left(0.05+0.15 \tau_{\mathrm{A}}\right)$ and $+\left(0.04+0.1 \tau_{\mathrm{A}}\right)$, $-\left(0.02+0.1 \tau_{\mathrm{A}}\right)$ over land and oceanic surfaces respectively, while the expected error of DB algorithm is estimated at $\pm\left(0.03+0.2 \tau_{\mathrm{M}}\right)$ (Levy et al., 2013; Sayer et al., 2015; Georgoulias et al., 2016). The input parameters $\tau_{\mathrm{A}}$ and $\tau_{\mathrm{M}}$ at the error estimation of the two algorithms correspond to the AOD derived by AERONET and MODIS respectively. 
The products of MODIS are provided at different levels of processing. The spatial resolution of MODIS level 2 (L2) is approximately $10 \mathrm{~km} \times 10 \mathrm{~km}$ at nadir-viewing geometry, while grids are increasing significantly with increasing viewing angle. In this paper MODIS Aqua C6 L2 is used and in addition to the $\mathrm{AOD}_{550 \mathrm{~nm}}$ the cloud fraction $(\mathrm{CF})$ over land, ocean and the DB CF over land are combined to provide full information on the cloud coverage during the Aqua overpass (Platnick et al., 2016). The orbit of Aqua meets the needs of providing the 3-dimensional overview and description of the dust event. Aqua, being part of the A-Train constellation of earth observation satellites, flies in formation with CALIPSO. Consequently, the synergy of Aqua-MODIS and CALIPSO-CALIOP results in the horizontal and vertical description of the dust event, hence on the 3-D overview.

For the vertical distribution and structure of the atmosphere the synergy of MODIS and CALIOP (Cloud Aerosol Lidar with Orthogonal Polarization) can provide a unique 3-D characterisation of dust outflows (Gkikas et al., 2016; Kosmopoulos et al., 2011). CALIOP, the main instrument on board CALIPSO, has provided information on the vertical distribution of aerosols and clouds (Winker et al., 2009) since June 2006. CALIPSO, the NASA-CNES collaboration project, is part of the A-Train constellation and therefore observes the same atmospheric layer as MODIS/Aqua at nadir viewing, with a delay of a few seconds only. The main CALIPSO products include the total attenuation backscatter coefficient at both 532 and $1064 \mathrm{~nm}$ and polarisation retrievals at $532 \mathrm{~nm}$. Based on the backscatter coefficient, the depolarisation ratio, the altitude of the atmospheric layers and the surface characteristics below the orbit of CALIPSO, the CALIOP algorithm (Omar et al., 2009, 2016) classifies the atmospheric masses among different feature types (clear air, cloud, aerosol, stratospheric feature, surface, subsurface or totally attenuated). In the case of aerosols, the algorithm further discriminates the atmospheric layers between marine, dust, clean continental, polluted continental/smoke, polluted dust elevated smoke, dusty marine, PSC aerosol, volcanic ash and sulfate/other. In this work, the CALIPSO level 2 Version 4.10 aerosol profile product is used.

\subsubsection{AERONET}

The AERONET measurements reported in this work were conducted at Thisio AERONET station (ATHENS-NOA), which is located in the capital of Greece, Athens, with a CIMEL sun photometer (CE318). The instrumentation, data acquisition, retrieval algorithms and calibration procedure conform to the standards of the AERONET and are described in detail in numerous studies (e.g. Holben et al., 2001; Dubovik et al., 2000). Typically, the total uncertainty in AOD for the field instrument under cloud-free conditions, is \pm 0.01 for $\lambda>440 \mathrm{~nm}$, and \pm 0.02 for shorter wavelengths. In this study, the hourly averaged data, which are cloud- screened and quality assured (Smirnov et al., 2000), were used. The temporal resolution of AERONET AOD measurements is about four measurements per hour in cloud-free conditions.

\subsection{Models}

\subsubsection{Meteorology and back-trajectories}

The final analysis data (FNL) of the National Center for Environmental Protection (NCEP) are used for the assessment of the meteorological conditions related to the uplift and transport of dust. The NCEP-FNL (final analysis) data are on $1^{\circ} \times 1^{\circ}$ grid and are available every $6 \mathrm{~h}$ (NCEP 2000). The analyses include meteorological parameters (pressure, geopotential height, temperature, wind, etc.) inside the boundary layer, at the surface and at 26 pressure levels from 1000 to $10 \mathrm{hPa}$. The HYSPLIT dispersion model (Stein et al., 2015) is used for the computation of air mass back-trajectories during the dust episode. The trajectories are calculated from 500-2000 m every $500 \mathrm{~m}$ over the Aegean Sea in order to define the transport paths of dust originally elevated at the coastal sources of northern Africa. HYSPLIT model is driven by NCEP-GDAS (FNL is also part of the GDAS and hence controls HYSPLIT's output accuracy) meteorological data at $1^{\circ} \times 1^{\circ}$ resolution (NCEP 2000).

\subsubsection{COSMO-ART simulations}

COSMO-ART is a regional atmospheric model which couples online meteorology and chemistry. COSMO is the operational numerical weather prediction model of the German and other European weather services (Baldauf et al., 2011) and is used as a regional climate model in a modified version CCLM (Rockel et al., 2008). ART (Aerosols and reactive trace gases) is the chemistry extension of COSMO. Detailed descriptions of the model, the physicochemical characteristics of the aerosol modes and the parameterisations of feedbacks of aerosols on radiation, temperature, cloud and ice condensation nuclei (CCN and IN) are given in Vogel et al. (2009), Bangert et al. $(2011,2012)$ and Rieger et al. (2014). The model domain used in this study is defined so that it includes the area of the dust source (NW Africa) and its transport path towards SE Mediterranean (from 24 to $42^{\circ} \mathrm{N}$ and from $5^{\circ} \mathrm{W}$ to $32^{\circ} \mathrm{E}$ ). The horizontal spatial resolution is $0.25^{\circ}$, while the vertical extent reaches $22.7 \mathrm{~km}$, stratified in 40 layers. The meteorological initialisation is performed using inputs from the ICON general circulation model (Zängl et al., 2015), i.e. from the operational model runs of the German Weather Service. Anthropogenic emissions are derived from the TNO-MACC III database (Kuenen et al., 2014), while the African dust emissions are calculated online, thus are case specific. Their hourly emission rate is parameterised according to the saltation processes as a function of friction velocity (when greater than a threshold), soil 
water content and surface roughness. More information on the exact methodology can be found in Vogel et al. (2006). Apart from the base-case run, a scenario with the online interaction between dust and radiation switched off is also performed.

\subsubsection{RTM simulations}

For the RTM simulations we used libRadtran (Mayer and Kylling, 2005) in order to produce gridded GHI, DNI, VIS and UV spectral irradiances and integrated values at the surface with the impact of dust as well as for clean (aerosolfree) and clear (cloud-free) sky conditions. The RTM simulations convert the satellite and ground-based cloud and aerosol products directly into high-resolution $(1 \mathrm{~nm})$ spectral irradiances (Emde et al., 2016). The main input is the AOD, which quantifies the exact impact of the dust particles at the local (Athens) and regional (Greece) levels. Other basic input parameters to the RTM simulations were the SZA, total ozone, reflectivity of the earth's surface and water vapour column. Thus, the RTM has been applied to MODIS level 3 AOD $(550 \mathrm{~nm})$ data with the spatial resolution of $1^{\circ} \times 1^{\circ}$ and to the CAMS 1-day AOD $(550 \mathrm{~nm})$ forecast to produce gridded spectra and spectrally integrated total SSR values. The AERONET AOD data in the station of Athens were also used as inputs to the RTM to quantify the impact of dust on SSR. The simulated SSR values using satellite and ground-based aerosol optical properties means that this approach covers all the recognised available aerosol data sources and the RTM outputs that could potentially be used for the proper assessment and corrections of solar power operational loads (Kosmopoulos et al., 2015).

When modelling clear (from clouds) but not clean (from aerosols) sky conditions, aerosol has a particularly important impact on the radiation budget (Schwartz et al., 2014) and hence the AOD, the Ångstrom exponent and the singlescattering albedo (SSA) are included in the RTM simulations. The output wavelength range of the radiative fluxes is $285-2800 \mathrm{~nm}$ in order to facilitate an investigation into the dependence of the irradiance spectrum on particular aerosol parameters for this specific dust case and at the same time to quantify the energy potential. Furthermore, in our RTM simulations, we used the default aerosol model according to Shettle (1989), the code for spectral irradiance (COSI) developed in one direction for the extraterrestrial solar source spectrum, the parameterisation of molecular bands provided by LOWTRAN for the gas absorption, and finally the SDISORT radiative transfer solver (Dahlback and Stamnes, 1991), which is appropriate for large SZAs making the simulated spectra outputs valid from 0 to $90^{\circ}$. The RTM simulations were calculated using a band parameterisation method based on the correlated K-approximation (Kato et al., 1999) and the exponential sum-fitting technique. This method has been found to be able to offer accurate estimates of the spectral irradiance at spectral intervals comparable with those provided by detailed line-by-line calculations in clear- and cloudy-sky conditions (Nyamsi et al., 2014).

\subsubsection{CAMS}

Forecast data (1 day) from the Copernicus Atmospheric Monitoring Service (CAMS), based on Monitoring Atmospheric Composition and Climate (MACC) reanalysis tools, were used to provide deeper understanding of the dust transport of the event and also to visualise the plume of dust aerosols. The CAMS data set includes modelling of aerosol and satellite data assimilation. The modelling part is based on ECMWF physical parameterisations concerning aerosol processes and mainly follows the aerosol treatment in the LOA/LMD-Z model (Boucher et al., 2002; Reddy et al., 2005). A detailed description of the model can be found in Morcrette et al. (2009) and Benedetti et al. (2009). In brief, it estimates dust particles emissions from $10 \mathrm{~m}$ wind, soil moisture, albedo in the UV-visible region and land coverage (Morcrette et al., 2008), sea-salt emissions are calculated using a source function (Guelle et al., 2001; Schulz et al., 2004) and other aerosol types emitted by domestic, industrial and transport activities are extracted from SPEW (Speciated Particulate Emission Wizard) and EDGAR (Emission Database for Global Atmospheric Research) annual- or monthly mean climatologies (Dentener et al., 2006). Removing aerosols from the atmosphere includes wet and dry decomposition and gravitational settling, and standard schemes for all three of them are used in the model. MODIS AOD at $550 \mathrm{~nm}$ data are assimilated into a database, applying a bias correction, which uses all available information to determine consistent bias estimates from multiple data sources (Dee and Uppala, 2009). The coupling of these data provide a database from 2012 at $1 \mathrm{~h}$ time steps at $0.4^{\circ} \times 0.4^{\circ}$ spatial resolution.

\section{Results}

\subsection{Synoptic description of the dust event}

As seen in Fig. 1, the establishment of a cold trough during 31 January-1 February 2015 over western Europe favours the formation of a low-pressure system at the Gulf of Genoa. The mean sea level pressure (m.s.l.p.) reaches $986 \mathrm{hPa}$ over Corsica at 12:00 UTC, 31 January 2015 (Fig. 1a). As the system propagates towards Italy and the Balkans, frontal activity along the northern Africa coastline results in increased near-surface wind speeds at this area (colour scale). Especially over the dust source areas located between the Gulf of Gabès in Tunisia and the Gulf of Sirte in Libya, wind speeds at $1000 \mathrm{hPa}$ exceed $15 \mathrm{~m} \mathrm{~s}^{-1}$ and dust particles mobilised are transported over the Mediterranean at the warm sector of the cyclone. The back-trajectories arriving over the Aegean Sea pinpoint to the dust sources as evident by the HYSPLIT $30 \mathrm{~h}$ in Fig. 1b. The air masses arriving at heights of $0-2 \mathrm{~km}$ over the Aegean Sea at 12:00 UTC, 1 February 2015 originate 


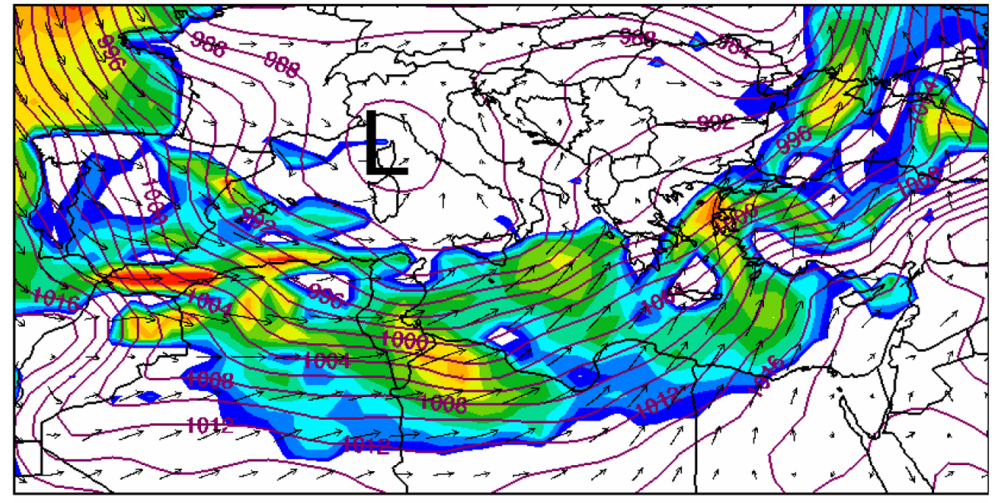

(a)

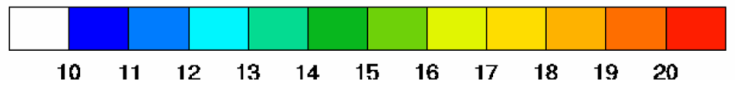

$\begin{array}{lllllllllll}10 & 11 & 12 & 13 & 14 & 15 & 16 & 17 & 18 & 19 & 20\end{array}$

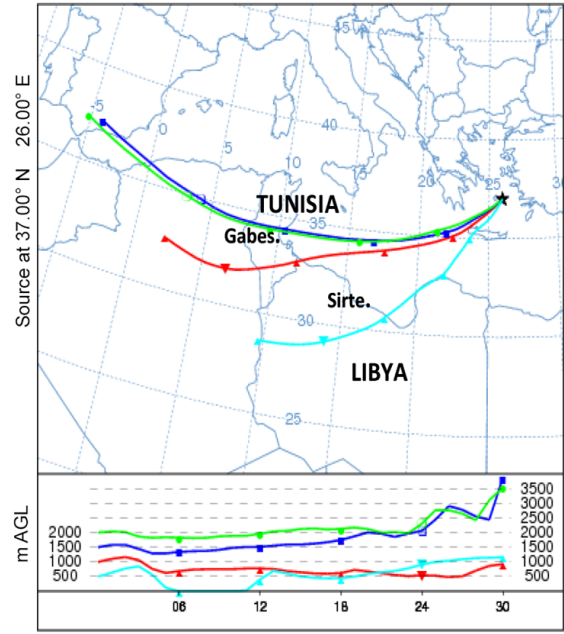

(b)

Figure 1. NCEP final analysis data (FNL) at 12:00 UTC, 31 Januray 2015 (a). The wind speed $>10 \mathrm{~m} \mathrm{~s}^{-1}$ at $1000 \mathrm{hPa}$ is shown (colour scale and vectors) overlaid with mean sea level pressure (contour lines). The low-pressure centre is denoted with L. The HYSPLIT back-trajectories arrive over the Aegean Sea at 12:00 UTC, 1 February 2015 (b).

from Tunisia and Libya and are embedded in the cyclonic circulation.

\subsection{3-D observation}

Figure 2 shows the spatial and temporal evolution of the true colour imagery (a), cloud fraction (b) and AOD (c) on the days before (top), during (centre) and after (bottom) the peak of the dust event on 1 February 2015. To present the horizontal distributions of MODIS parameters the domain of the eastern Mediterranean Sea is divided into grids of spatial resolution $0.1^{\circ} \times 0.1^{\circ}$ deg each, and accordingly the closest MODIS retrieval is assigned to each grid. Note that the days before and after the dust peak were extensively cloud covered (the relationship between AOD and CF is described by many researchers, e.g. Grandley et al., 2013). Elevated values of AOD (1-3) were observed up to 3 days prior and after the peak (not shown). Based on Fig. 2c centre panel, the dust plume is extended dramatically in the horizontal eventually reaching the Black Sea region with AOD values of similar order but with different lateral characteristics, as we will discuss in Sect. 3.4.2. An increase of AOD from the west to the east is observed, reaching maximum values over southern Greece. The dust plume yields AOD $_{550} \mathrm{~nm}$ values larger than 1 , while values as high as 3 are persistently evident in the centre of the plume. A decreasing gradient to the northeast is also present along the dust plume. Over the larger domain of the western Turkey the high CF and the absence of $\mathrm{AOD}_{550 \mathrm{~nm}}$ values prevent the retrieval of the horizontal evolution of the dust plume over Turkey.

Figure 3 shows the 3-D profiling of the dust plume (see Amiridis et al., 2009, 2015; Kosmopoulos et al., 2014; Mamouri et al., 2016). The horizontal distribution is pro- vided by MODIS/Aqua C6 L2 AOD $550 \mathrm{~nm}$ (left panel) while CALIPSO provides the extinction coefficient profiles at $532 \mathrm{~nm}$ (upper right) and the aerosol subtype classification (lower right). The total effect of integrated AOD profile from CALIPSO as input to the RTM simulations in terms of SSR output sensitivity and effectiveness in solar energy exploitation, is similar at the surface $( \pm 5 \%)$ compared to the total AOD from MODIS observations (Kosmopoulos et al., 2014); thus in all RTM simulation cases we used the total AOD values from MODIS and CAMS as input (Sect. 3.4.1). For the specific dust episode, the maximum AOD observed with CALIOP is about 3 in the centre of the plume, while the corresponding AOD from MODIS is almost 3.5 over the Greek region and 3 over the plume part that CALIPSO passes over. At the same time, the laser backscatter signal of CALIOP completely attenuates at particulate column optical depths of $\sim 3$, while for higher optical depths it cannot measure the full extent of the vertical column (Vaughan et al., 2009). The plume consists mainly of dust aerosol, and polluted dust and dusty marine at the edges, in agreement with similar studies (Gkikas et al., 2016; Papayiannis et al., 2005; Li et al., 2004). Based on the CALIPSO backscatter coefficient and the depolarisation ratio $(532 \mathrm{~nm})$ profiles, it is possible to decouple the pure dust component from the polluted dust and dusty marine mixtures, hence to estimate the dust contribution to the total AOD (Tesche et al., 2009). According to CALIPSO the contribution of dust AOD to the total AOD gradually increases from $70 \%$ to the south of the dust plume to $100 \%$ in the region between 34 and $39.5^{\circ}$ latitude. The dust plume extends vertically as high as $3.5 \mathrm{~km}$ a.s.l. At the edge of the plume $\left(31\right.$ to $33^{\circ} \mathrm{N}$ ), extinction coefficient values at $532 \mathrm{~nm}$ are around $0.2 \mathrm{~km}^{-1}$, while in the centre of the plume $(35$ 

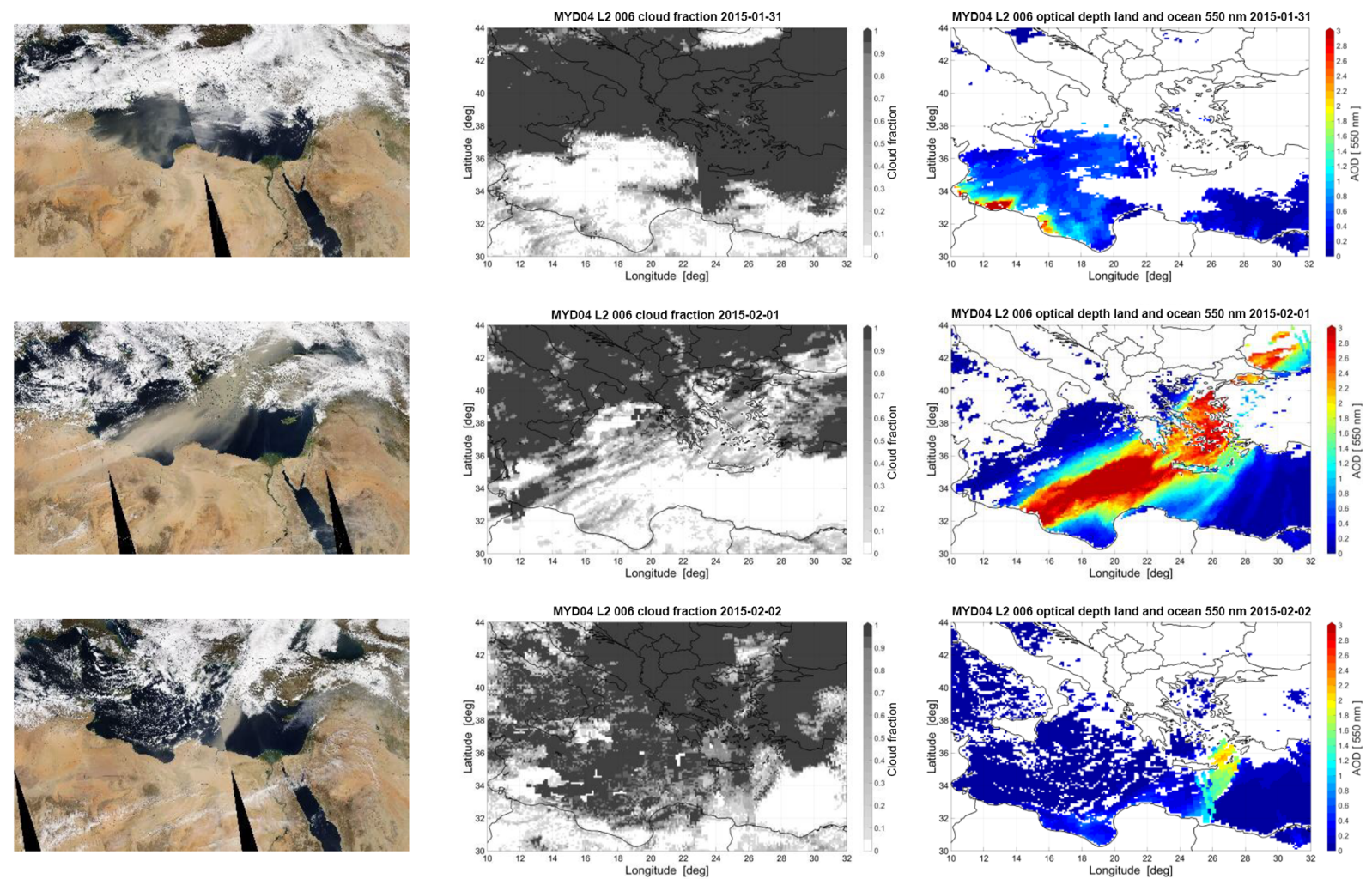

(a)

(b)

(c)

Figure 2. Satellite observation of the temporal evolution of the dust incursion peaking on 1 February 2015 over Greece from MODIS/Aqua satellite data. (a) True colour imagery based on bands 1, 3 and 4. (b) Evolution of the cloud fraction and (c) AOD on the day before (top), during (centre) and after (bottom) peak dust. Note that the days on either side of the peak are extensively cloud covered. High values of AOD were observed up to 3 days before and after the peak.
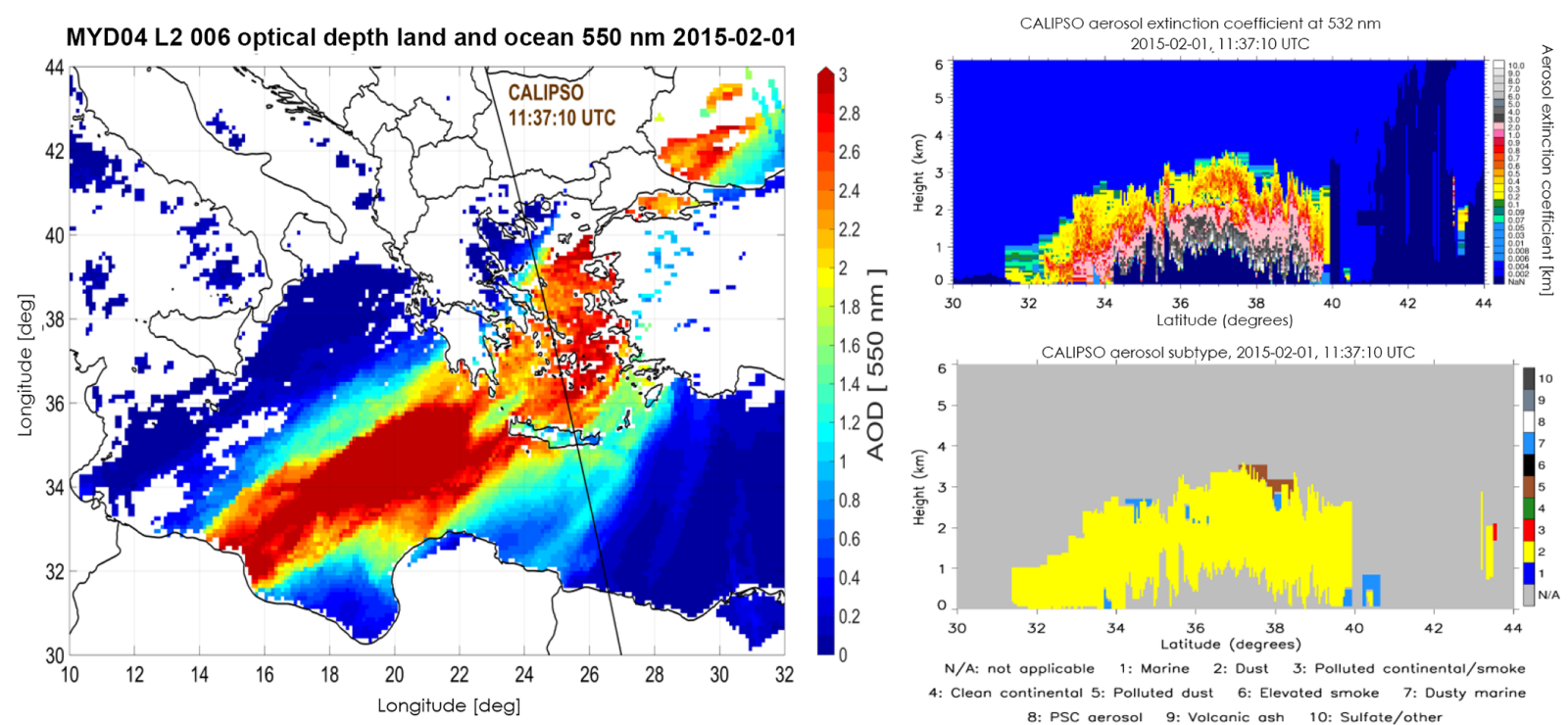

Figure 3. 3-D profiling of the dust incursion on 1 February 2015: spatial extent provided by MODIS level 2 (collection 6) AOD at 550 nm (left) together with CALIPSO profiles at $532 \mathrm{~nm}$ of the extinction coefficient (upper right) and aerosol subtyping (lower right) in the profile taken at 11:37 UTC (indicated by the distinct black-coloured track line in the left panel). 
Land AOD-mean (complete), 2006-2010, seasons: all, QA: prefiltered, at all_locations, outliers removed

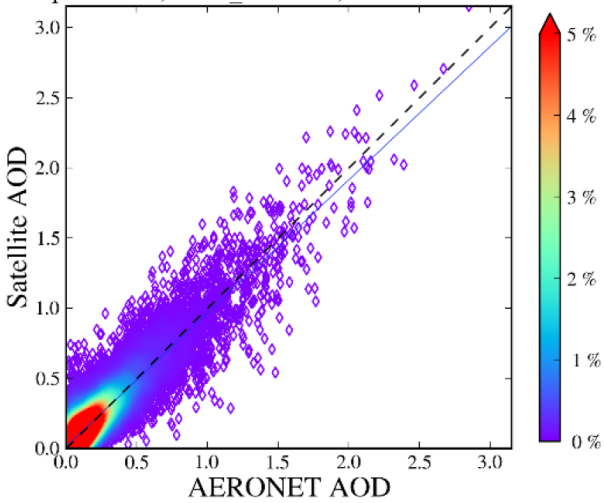

AMODIS: $\mathrm{R}^{2}=0.80, \mathrm{RMSE}=0.09, \mathrm{y}=0.95 \mathrm{x}+0.01, \mathrm{~N}=47483$, outlicrs $=1371$

(a)
Land AOD-mean (complete), 2006-2010, seasons: all, QA: prefiltered, at ATHENS-NOA, outliers removed

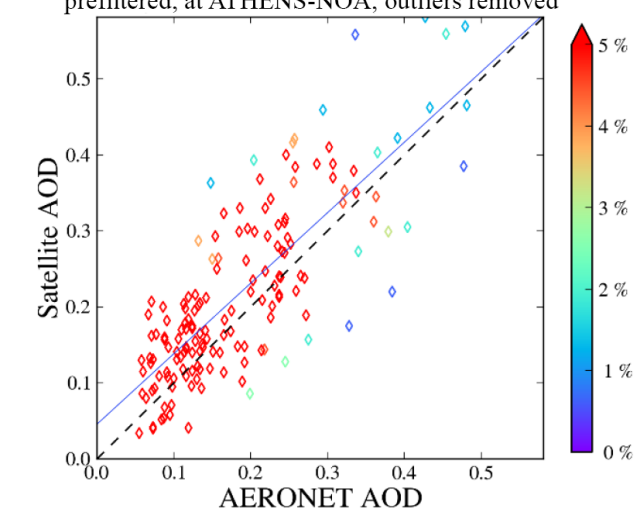

- AMODIS: $\mathrm{R}^{2}=0.63, \mathrm{RMSE}=0.08, \mathrm{y}=0.93 \mathrm{x}+0.05, \mathrm{~N}=156$, outliers $=0$

(b)

Figure 4. Scatter plots of satellite AOD $(550 \mathrm{~nm})$ from MODIS/Aqua vs. coincident AOD from AERONET for the 5-year period 2006-2010 with outliers removed. Panel (a) shows the global record and (b) is for the ATHENS-NOA site. The colour bar describes the percentage frequency of AOD values occurrence (source of the plots: https://giovanni.gsfc.nasa.gov/mapss_explorer/).

to $40^{\circ} \mathrm{N}$ ), the lidar signal is totally attenuated below $1 \mathrm{~km}$. The aerosol extinction coefficient at $532 \mathrm{~nm}$ increases from $0.2 \mathrm{~km}^{-1}$ at the top of the dust layer, to $2 \mathrm{~km}^{-1}$ at about $1.5 \mathrm{~km}$ distance from the top of the layer and it reached values of $10 \mathrm{~km}^{-1}$ just before the signal was significantly attenuated. These observations are similar to the radiative properties and the corresponding heights of desert dust aerosol measured and calculated by Haywood et al. (2001) and Hess et al. (1998).

\subsection{Ground-based aerosol data}

In order to provide a context for the high AOD values observed in the region during the extreme dust incursion on 1 February 2015, Fig. 4 presents scatter plots obtained from the multi-sensor aerosol products sampling system (MAPSS: https://giovanni.gsfc.nasa.gov/ mapss_explorer/) (Petrenko et al., 2012) of the MODIS/Aqua satellite AOD at $550 \mathrm{~nm}$ compared to coincident groundbased AOD measured by CIMEL sun photometers in AERONET (Holben et al., 1998). The data presented are outlier free (the percentage of the outliers represent less than $0.5 \%$ of the data (250 points) of total coincident values), spanning the 5-year period: 2006-2010 (inclusive) for the entire global record $(\approx 50 \mathrm{~K}$ coincident values $)$ together with the local record at the ATHENS-NOA site ( $\approx 150$ values). The CIMEL at the Athens site has been in operation since 7 April 2008 and provides spectral AOD data at levels 1.0 (1993 days), 1.5 (1870 days) and 2.0 (1514 days). The coefficient of determination between the satellite and groundbased AOD is high $0.63 \leq R^{2} \leq 0.64$ for Athens (and very high globally: $0.80 \leq R^{2} \leq 0.81$ ) for both satellite sensors and reflects low root mean squared errors $(0.07 \leq \mathrm{RMSE} \leq$ 0.09). In all cases, a strong high frequency of occurrence peak is apparent in the range $0 \leq \mathrm{AOD} \leq 0.4$. This peak is associated with a modal value of AOD $(\approx 0.16$ globally and $\approx 0.13$ for Athens). The extreme dust incursion event on 1 February 2015 is therefore expected to load the aerosol optical depth over the ATHENS-NOA site and be clearly distinguishable from the baseline value of $\approx 0.13$.

AERONET ground-based retrieval of level 1.0 (Version 2) AOD from ATHENS-NOA site, provides approximately hourly records that enable tracing the temporal evolution of the aerosol load (Fig. 5). Values reach up to 2.3-2.5 on 1 February 2015. In Fig. 5, upper plot, level 2.0 AOD are marked. Level 2.0 data are usually used due to higher quality, and in this particular case, have the same data points as level 1.5 data, which are provided by the automatic cloud filtering algorithm of AERONET (Smirnov et al., 2000). As shown in Fig. 5, during the period of very high AOD values (before 12:00 UTC, AOD at $500 \mathrm{~nm}$ is higher than 1.9) the cloud-screening procedure filtered out about $70 \%$ of data points (4 out of 13 passed this test). High AOD values in combination with rapid variation of them lead to the above result. Thus, for studying this dust case, we will use the level 1.0 AOD products and level 1.5 inversions retrievals, keeping in mind the higher uncertainty that rises from this choice. The cloud-screened inversion data products derived from sky radiance measurements provided by the CIMEL were also used, and both the SSA and the aerosol volume size distribution, which are key aerosol properties for aerosol classification (see Taylor et al., 2015 and references therein), are presented in Fig. 5. The level 1.5 SSA presents high values in the near UV at $470 \mathrm{~nm}$ that are in excess of 0.85 (rising to $\approx 0.97$ in the visible) but importantly, also have extremely low percentage sphericity $(0.2-0.6 \%)$ as expected for aged dust grains (Dubovik et al., 2002). The typical signature of 

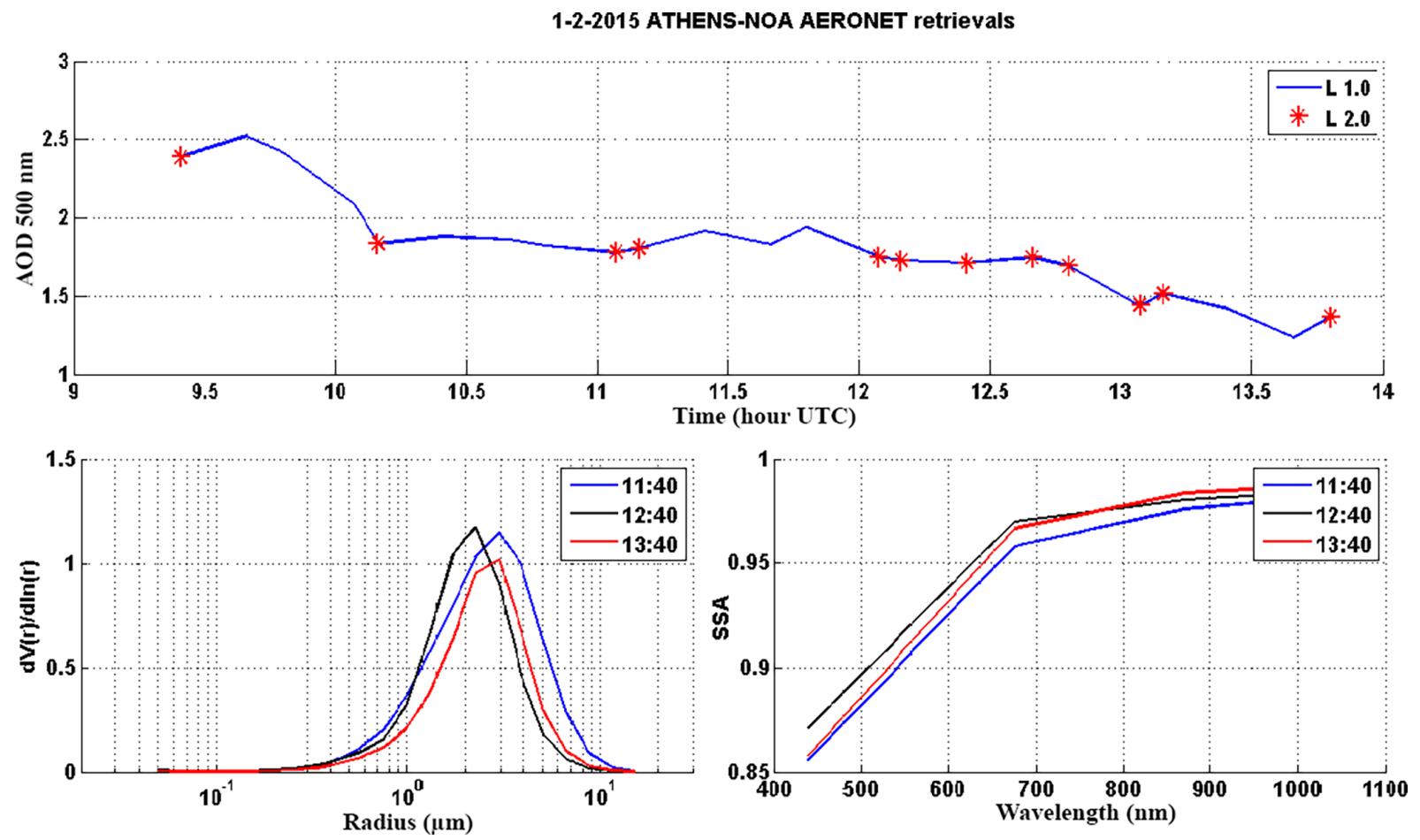

Figure 5. Temporal evolution of the AOD at $500 \mathrm{~nm}$ obtained from the level 1.0 and 2.0 inversion algorithm of the CIMEL sun photometer at the Athens site during the day of peak dust incursion over the region on 1 February 2015 (upper) together with aerosol volume size distribution (lower left) and the spectral SSA (lower right) retrieved from the level 1.5 inversion algorithm on the same day.

dust is also demonstrated by the level 1.5 aerosol volume size distribution, which shows a large peak centred on 3$4 \mu \mathrm{m}$ in line with expected microphysical properties of desert dust (Kinne et al., 2003; Taylor et al., 2014).

\subsection{Impacts of dust on surface solar radiation}

\subsubsection{RTM simulations}

The intensity of this dust case was further investigated by comparing the induced attenuation in SSR with the mean monthly attenuation percentages over Athens (ATHENSNOA AERONET site). For this reason we calculated the mean monthly level 1.5 AOD values and ranges based on an 8-year AERONET climatology (7 April 200831 March 2016) and the results are shown in Fig. 6. The range of climatological AODs is $\approx 0.11-0.22$ with two peaks in spring and summer. Spring is the most favourable season for dust transport from northern Africa to Greece (e.g. Kalivitis et al., 2007; Kosmopoulos et al., 2008; Gerasopoulos et al., 2007, 2011), while the summer peak is related to the transport of pollution from continental Europe (e.g. Gerasopoulos et al., 2011) and increased agricultural burning and forest fires (e.g. Athanasopoulou et al., 2014). The range of monthly minimum and maximum AOD values revealed two different peaks in winter (2.36) and autumn (1.63), something that indicates that the most extreme aerosol events occur in these two seasons. This finding mainly has to do with intense dust transport in February (our dust case with $\mathrm{AOD}=1.21-2.36$ and median value 1.71) and urban/industrial aerosols (Fameli et al., 2015; Kalivitis et al., 2007; Kosmopoulos et al., 2008), as well as wood burning cases that are directly related to the Greek economic crisis the last 7 years (Vrekoussis et al., 2013). These values were incorporated into the RTM and we simulated the GHI and DNI percentage attenuation at 40 and $60^{\circ}$ of solar zenith angle which are typical solar elevation angles for the region of Greece in the winter season. The results show significantly higher attenuation values for larger SZAs and for DNI in general. In particular, at SZA of $40^{\circ}$, the percentage decrease for GHI is around $-5 \%$ and for DNI $-17 \%$, while at $60^{\circ}$ of SZA, the corresponding values are -7 and $-25 \%$. All the above results are comparable with similar studies (Papadimas et al., 2012; Tumock et al., 2015; Qian et al., 2007) in terms of AOD range (0.11-0.25 in EM) and mean aerosol radiative forcing under cloudless conditions $(\approx-5 \%$ for GHI and $-15 \%$ for DNI). Under the impact of the studied dust event as measured by AERONET, with median AOD in the specific site around 1.71 , the GHI decrease is $-37 \%$ at $40^{\circ}$ and $-49 \%$ at $60^{\circ}$, and the DNIs are -80 and $-90 \%$ at 40 and $60^{\circ}$ respectively.

In Fig. 7 we simulated the radiative transfer (RT) using the AERONET station in Athens in order to highlight the 
(a)

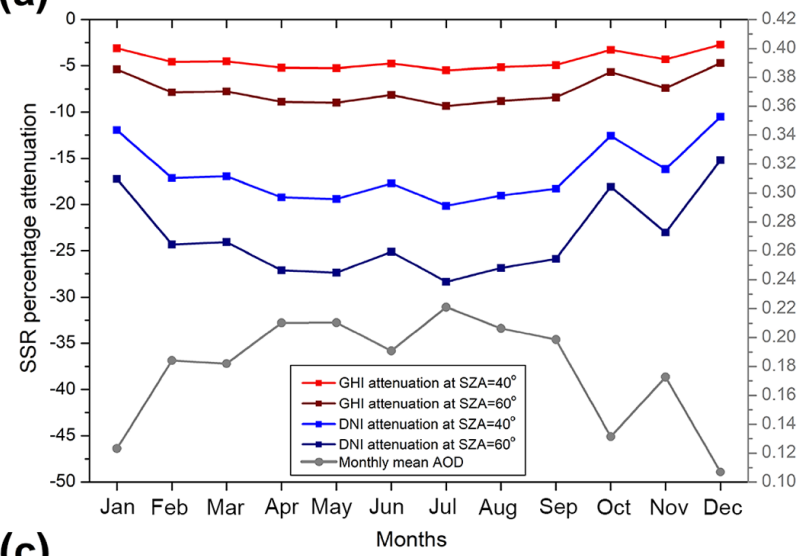

(c)

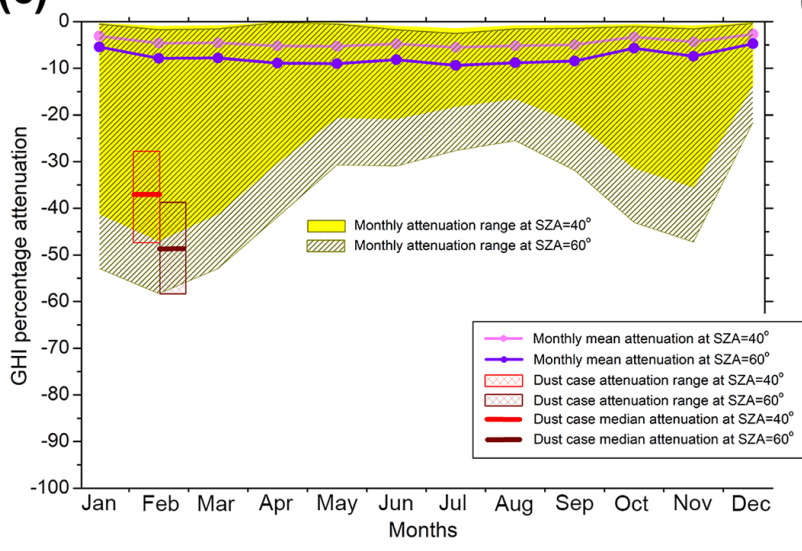

(b)

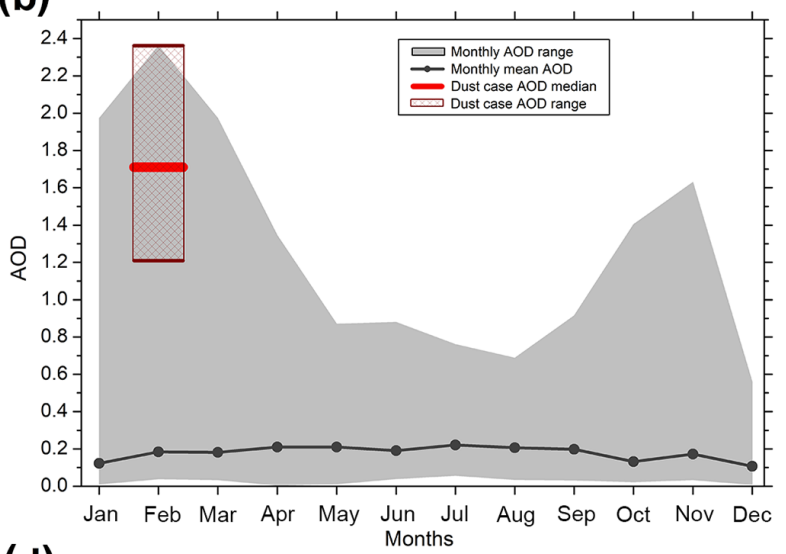

(d)

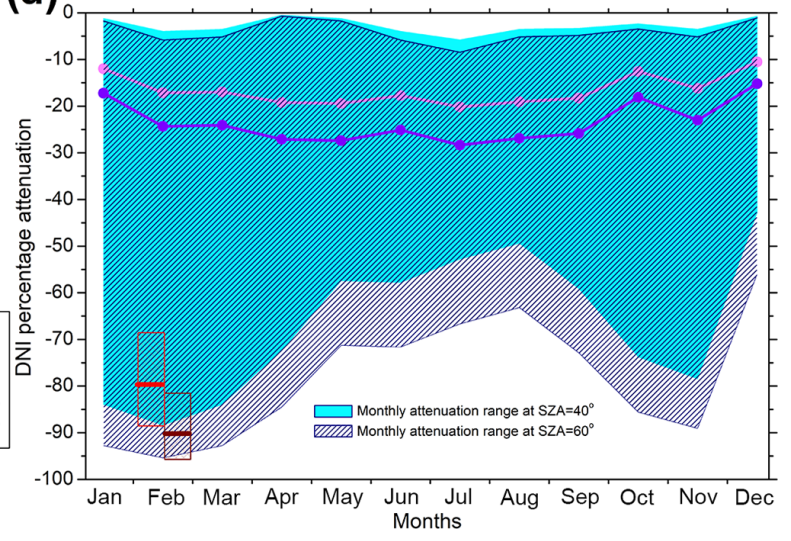

Figure 6. Mean monthly GHI and DNI percentage attenuation in Athens as a function of solar zenith angle and AOD (a) together with the mean monthly range of AOD (b), the percentage attenuation range for GHI (c) and DNI (d). The red-shaded insets show the corresponding median values and ranges at the peak of the strong dust incursion over the region on 1 February 2015.

temporal variation of this dust case in $1 \mathrm{~h}$ resolution, as well as the mean dust impact on the solar spectrum. In Fig. 7a we show the normalised spectral impact on the GHI for the region $285-1050 \mathrm{~nm}$ as spectral ratio of the irradiance under actual aerosol conditions to that under aerosol-free conditions. The higher spectral effect is found in the UVA region (around $400 \mathrm{~nm}$ ) with attenuation of the order of $68 \%$, while in the visible $(400-700 \mathrm{~nm})$ and the infrared regions the attenuations are almost 60 and $54 \%$ respectively, indicating a weaker absorption of dust in these two spectral regions (Kaufman et al., 2000). These results are similar to relevant studies under various weather and atmospheric conditions (Dimberger et al., 2015; Ishii et al., 2013). In Fig. 7b the corresponding integrated ratios for GHI and DNI are shown. The stronger effect on DNI compared to the GHI is apparent, which in Fig. 7b is depicted with DNI ratio values close to zero (absolute blocking) for the entire duration of the day.

In Fig. 8 the effect of dust is shown for various spectral integrals and quantities over Athens for the 1 February 2015. These estimates were derived from RTM calculations based on actual aerosol conditions (AERONET data in Athens) and dust-free conditions. Specifically we show the diurnal course of DNI, GHI, UV index and irradiance in the visible (VIS), together with the percentage attenuation for all occasions. Under dust-free conditions, the DNI ranges from 450 to $230 \mathrm{~W} \mathrm{~m}^{-2}$, the GHI from 500 to $270 \mathrm{~W} \mathrm{~m}^{-2}$, the VIS irradiance from 270 to $150 \mathrm{~W} \mathrm{~m}^{-2}$ and the UV index from 2.6 to 0.8 . Under the dust conditions, the highest values appeared in GHI $\left(250-120 \mathrm{~W} \mathrm{~m}^{-2}\right)$ and the lowest in DNI (40$10 \mathrm{~W} \mathrm{~m}^{-2}$ ) indicating the strong effect of dust on the direct component of SSR. These patterns are reflected in the percentage attenuation as well, with mean attenuation of $-93 \%$ in DNI, followed by UV index $(-70 \%)$, VIS $(\approx-57 \%)$ and GHI $(-53 \%)$ which are the lowest attenuations compared to all the other SSR fluxes.

Taking into account the significance of forecasting the reduction in SSR, as in the case of the particular dust plume, e.g. for CSP or PV installation management (PVs exploit the GHI and CSPs the DNI), in Fig. 9 we evaluated the CAMS forecast at 12:00 UTC from both the total and dust AOD at $550 \mathrm{~nm}$ found in the data set described in Sect. 2.2.4 in terms of spatial and quantitative characteristics. The dust AOD was found to be similar to the total AOD (dust AOD/total AOD $>0.9$ in the area), something that was depicted in the 

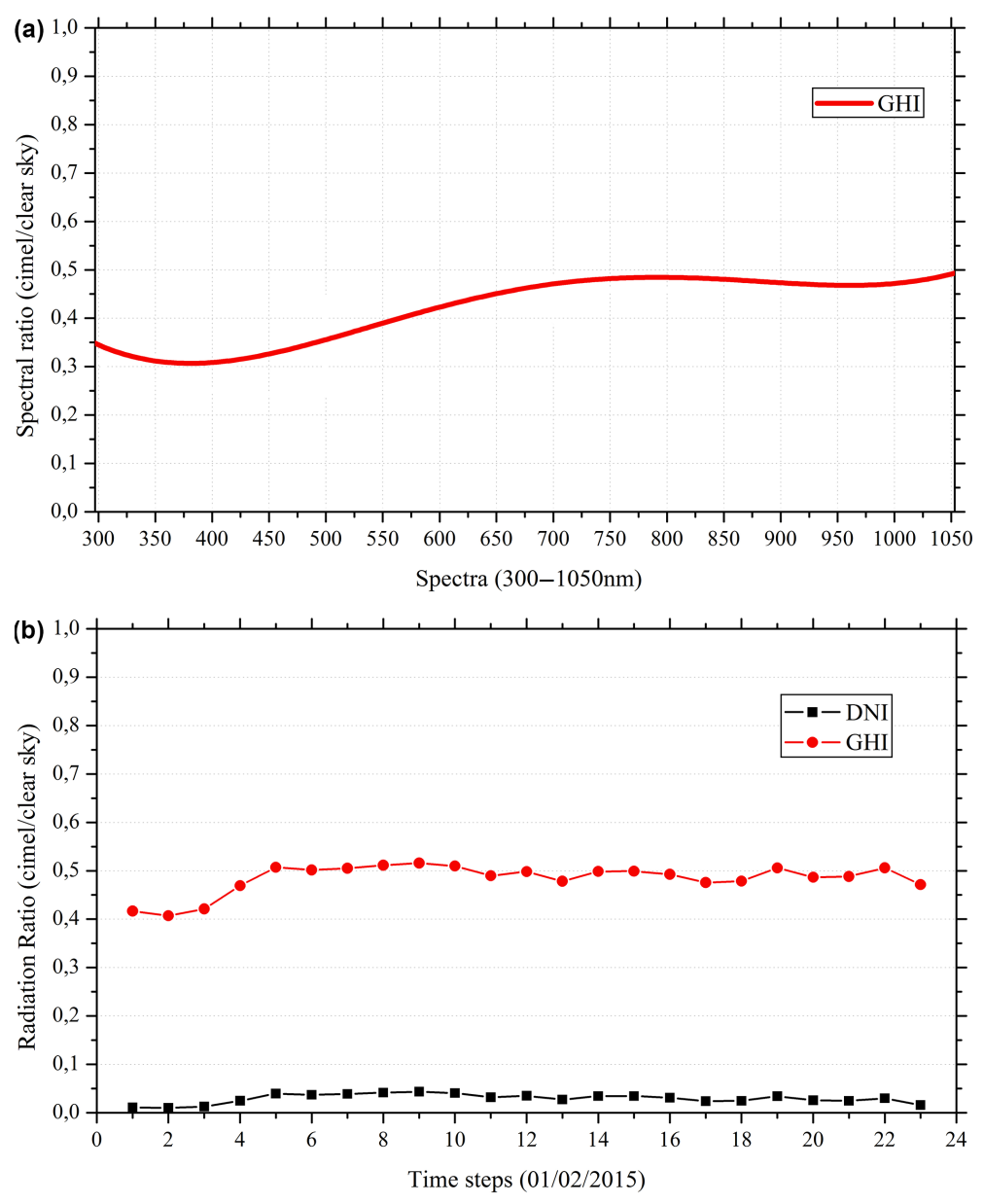

Figure 7. (a) The spectral effect of the extreme dust event of 1 February 2015 at the Athens station as depicted by the ratio of the AERONET Cimel sun photometer irradiance to the clear-sky irradiance calculated with a RTM for the same atmospheric conditions. Note the increased attenuation at shorter wavelengths. (b) Temporal evolution of the hourly value of the ratio for the GHI and DNI output by the RTM.

temporal (not shown) and spatial extent of the dust plume, demonstrating the effectiveness of the CAMS and the fact that, during dust outbreaks, the concentration of dust is tens of times greater than other aerosol species (Diaz et al., 2001). Figure 10 presents the RTM simulations using the CAMS AOD, as well as a direct comparison between the MODIS derived and simulated results with the CAMS 1-day forecasts. At Fig. 10a we present the MODIS level 3 and CAMS AODs at $550 \mathrm{~nm}$ in order to identify the observed (MODIS) and simulated/forecasted (CAMS) dust plume distribution, extent and AOD value intensity. The CAMS simulation follows MODIS's observed dust plume extent, approaching its distribution but underestimating the peak AOD values (maximum MODIS values $\approx 3.5$ and CAMS $\approx 1.9$ over the Greek region). This underestimation pattern of the peak AOD values is a consequence of imperfect forecasted meteorology and fading impact of the initial assimilation of MODIS AOD information on CAMS performance (MACC, 2015; Allen et al., 2013). Yet, despite this difference, the impact on the energy and SSR simulations is of the order of $10 \%$ (see be- low description) in most cases (>90\% of the spatial coverage), which highlights that CAMS 1-day forecasts are of great value and useful for solar energy potential planning and policies (Langerock et al., 2015; Charabi and Gastli, 2015; Kosmopoulos et al., 2015, 2017; Ruiz-Arias et al., 2016). Since the main inputs to the RTM are the AOD and the SZA, which can both be forecasted (CAMS AOD) and precalculated (SZA), the real time spatial and temporal estimation of the dust events impact on SSR is realistically feasible. At Fig. 10b we simulated GHI (upper) and DNI (lower) under aerosol-free and under MODIS and CAMS aerosol conditions, near local noon. In all cases we applied smoothing techniques in terms of data fitting to contour lines for better visualisation results. The SSR simulations were calculated with the impact of the dust as characterised in terms of high AOD values from MODIS level 3 values and CAMS 1-day forecast. The retrieved AOD for the RTM calculations is at $550 \mathrm{~nm}$, with spatial resolution of $1^{\circ} \times 1^{\circ}$ and $0.4^{\circ} \times 0.4^{\circ}$ (MODIS and CAMS respectively). The temporal resolution of MODIS overpass imaging is about 1 per day while for 

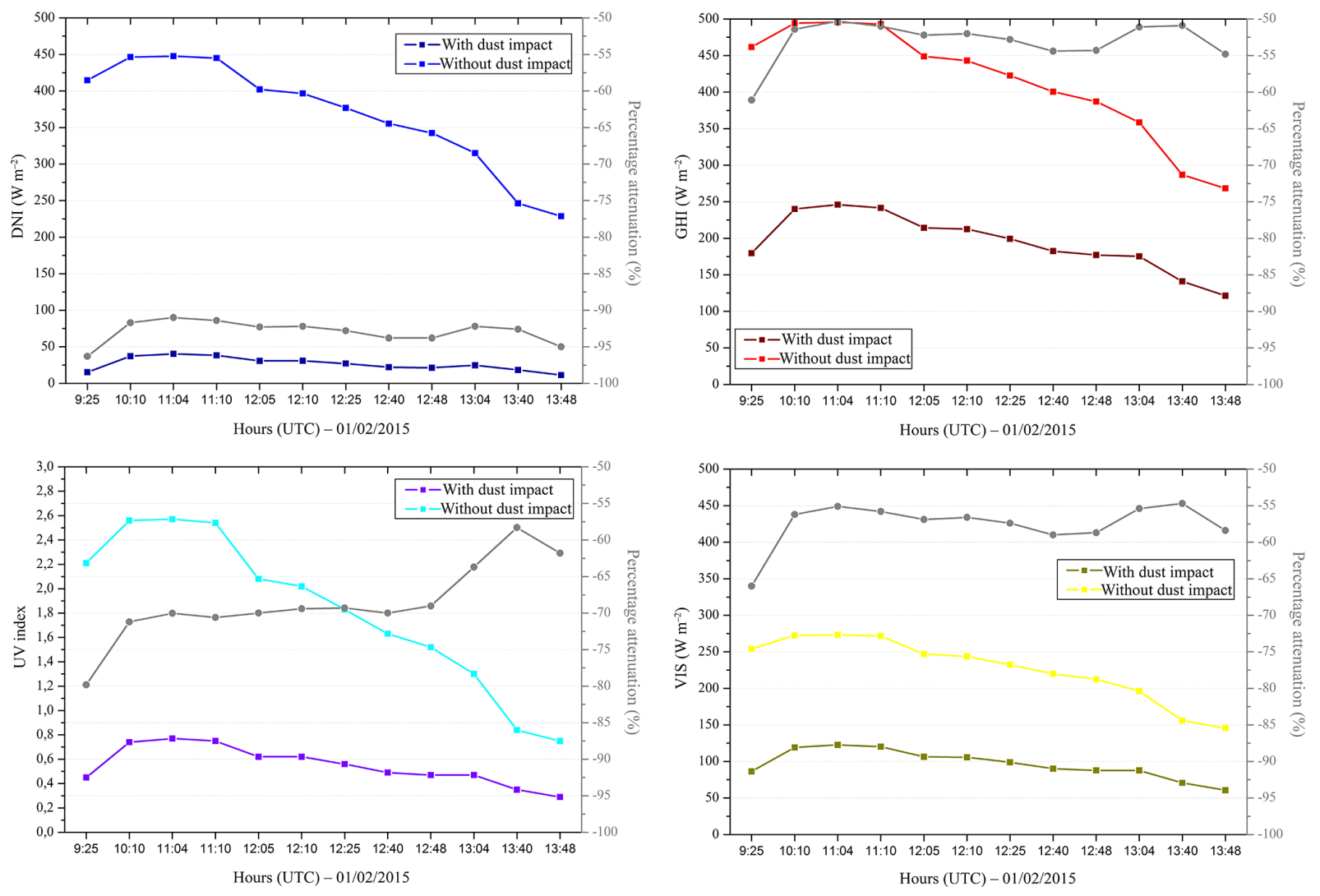

Figure 8. Temporal evolution of GHI, DNI, UV index and VIS irradiances during the extreme dust event of 1 February 2015 at the Athens station. The modelled values (without dust impact) coincident with AERONET Cimel measurements (with dust impact) are shown together with the $\%$ attenuation due to the impact of dust.
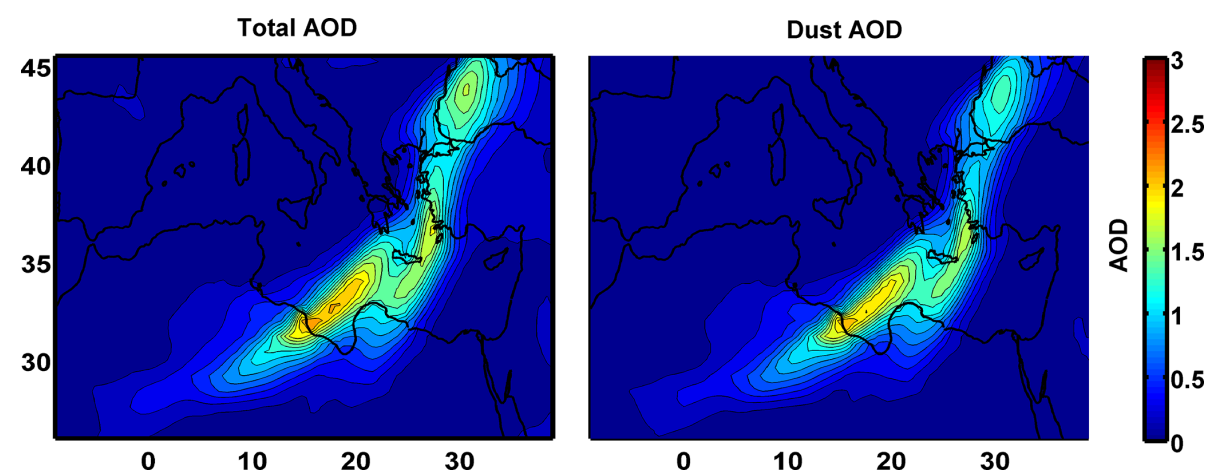

Figure 9. The spatial extent of total AOD (left) and dust AOD (right) at $550 \mathrm{~nm}$ provided by the CAMS. These maps depict predictions by the MACC 1-day forecast (spatial resolution: $0.4^{\circ} \times 0.4^{\circ}$ ). The maps correspond to 12:00 UTC, when maximum AOD $\approx 2.3$. The temporal resolution of the forecast is $1 \mathrm{~h}$.

the CAMS simulation it is 1 per hour, also highlighting the ability of the CAMS to provide significant information on the temporal evolution of solar energy availability. The panels in Fig. 10c describe the impact on energy in terms of percentage attenuation of SSR, indicating the radiative impact of the dust plume over Greece. The simulated results showed mean GHI values of about $500 \mathrm{~W} \mathrm{~m}^{-2}$ for aerosolfree conditions, while for full aerosol conditions this value is reduced to about $300 \mathrm{~W} \mathrm{~m}^{-2}$. The corresponding radiation values of DNI are $450 \mathrm{~W} \mathrm{~m}^{-2}$ for clean and clear sky and around $80 \mathrm{~W} \mathrm{~m}^{-2}$ for dust event conditions. We need to highlight as well that the maximum AOD that was simulated with the RTM was of the order of 3.5, which classifies this dust event as one of the most intense cases in the eastern Mediterranean. In general, spring presents the higher frequency of dust events (Gerasopoulos et al., 2007, 2011; Gkikas et al., 


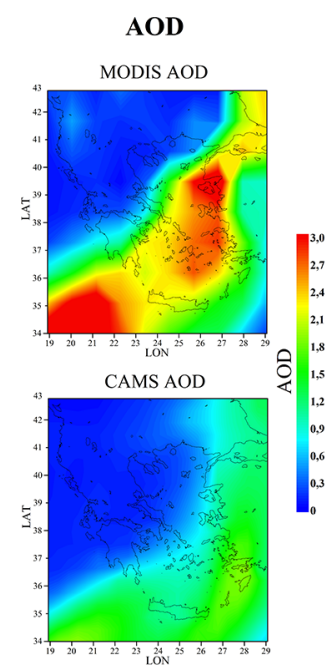

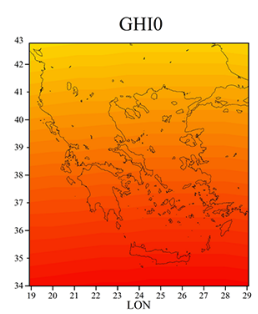

DNIO

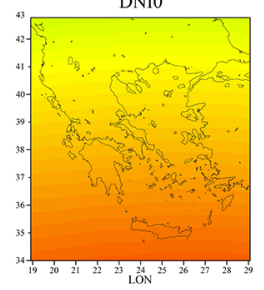

GHI \& DNI

GHI MODIS

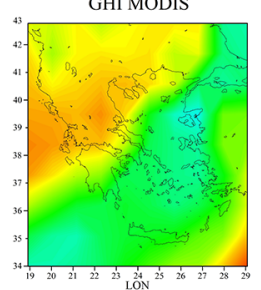

DNI MODIS

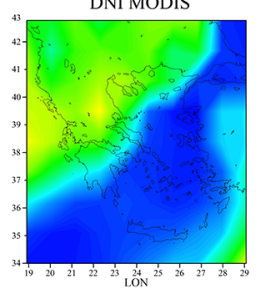

GHI CAMS

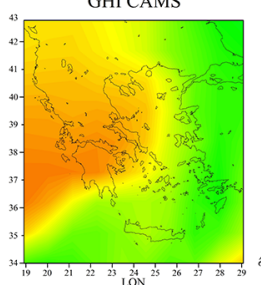

DNI CAMS

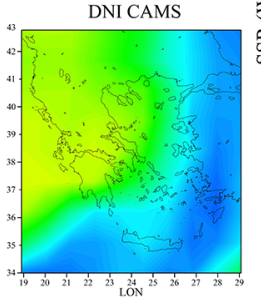

Energy impact

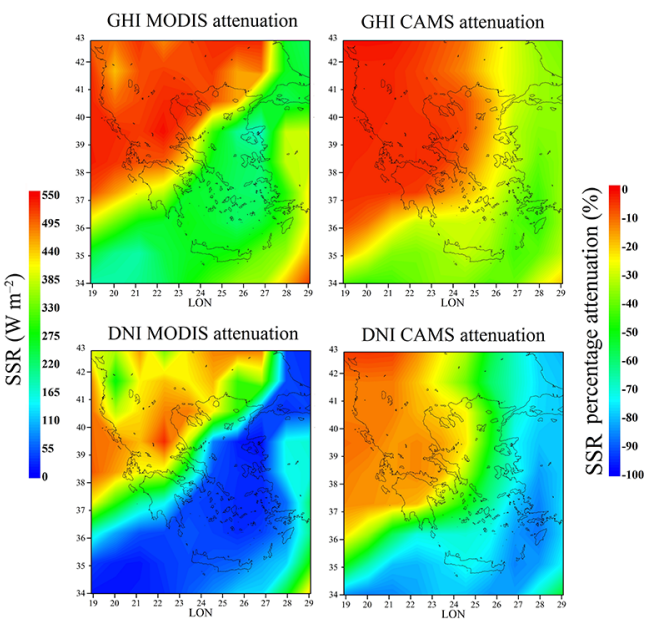

Figure 10. (a) AOD from MODIS level 3 and the CAMS 1-day forecast. (b) RTM simulations at local noon on the day of the incursion on 1 February 2015 for GHI and DNI. GHIO and DNI0 represent the simulations without dust (with only the effects of SZA). (c) The energy impact in terms of percentage attenuation relative to the dust-free simulations for GHI and DNI under MODIS- and CAMS-based AODs. For the GHI, the attenuation is about $30-70 \%$ for MODIS and about $30-60 \%$ for the CAMS. For the DNI, the attenuation is about $70-100 \%$ for MODIS and about $60-90 \%$ for the CAMS.

2012; Kosmopoulos et al., 2008, 2017), while in winter more intense dust events occur (Kalivitis et al., 2007). The percentage impacts of the plume (Fig. 10c) is in the range 30-70\% (MODIS) and 30-60\% (CAMS) for the GHI and 70-100\% and $60-90 \%$ for DNI, convincingly highlighting and illustrating the extreme attenuation of the direct component of the total SSR and at the same time quantifying the energy exploitation losses for PV and CSP applications. Overall, concerning the GHI and DNI percentage differences for the MODIS- and CAMS-based RTM simulation, we found that the CAMS forecasts overestimate the SSR values under high aerosol loads, indicating the limited ability of MACC to predict high AODs (MACC, 2015), while it can efficiently capture the dust plume extent and distribution. As a result, higher percentage differences on DNI following the highest AOD values and the lowest $\mathrm{SSR}$ values with minimum induced energy impact (DNI $<50 \mathrm{~W} \mathrm{~m}^{-2}$ ) is found. The percentage differences for GHI reach $80-100 \%$ for highest AOD values as well, with mean representative GHI attenuation below $50 \%$ (see Fig. 10c), highlighting the usefulness for energy forecasting needs and applications.

\subsubsection{COSMO-ART simulations}

Figure 11a depicts the event as captured by the COSMOART model application. In particular, the spatial distribution of the total AOD values (at $550 \mathrm{~nm}, 12: 00$ UTC) is comparable with the respective satellite (MODIS) retrieval. Peak values are simulated over the Aegean Sea and they are higher $(\mathrm{AOD}=5.2)$ compared to the satellite ones $(\mathrm{AOD}=3.5)$. This is partly related to the higher spatial resolution of the model run $\left(0.25^{\circ}\right)$ in comparison to the satellite image $\left(1^{\circ}\right)$. Nevertheless, uncertainties in the dust source functions within aerosol models are common, and are usually treated by model tuning with respect to observations (e.g. Vogel et al., 2006; Miller et al., 2004), but this is outside the scope of the current study.

The implications of the interaction between the African dust plume and meteorology are selectively shown in Fig. 11 (b and c plot). In particular, the incoming solar radiation in terms of GHI and DNI is examined, and their response to the dust plume during the daytime period (mean maximum AOD value $\sim 3.5$ ) is shown. As expected, the spatial pattern of the reduced solar energy that reaches the surface resembles that of the dust plume (Fig. 11a) because of the scattering and absorption of the incoming solar radiation by the dust particles. This decrease is more pronounced for the DNI, reaching values up to $-180 \mathrm{~W} \mathrm{~m}^{-2}$, while the effect on the diffuse solar radiation is less intense (up to $-100 \mathrm{~W} \mathrm{~m}^{-2}$, not shown). The effect on the GHI at the surface below the dust plume ranges between $-200 \mathrm{Wm}^{-2}$ (dust core) and $-20 \mathrm{~W} \mathrm{~m}^{-2}$ (dust edges), implying that the usage of solar energy in these areas (Cyclades and Crete) is greatly affected during the severe dust storm. This finding is comparable with values estimated in Rémy et al. (2015), i.e. an effect of $-300 \mathrm{~W} \mathrm{~m}^{-2}$ at the heart of a dust storm over NE Africa (AOD 3). The radiative effect of another dust storm over western Europe (Bangert et al., 2012) was found to be smaller, as expected due to the low AOD values (up to 0.5 ). Considering the radiative efficiency (aerosol radiative effect per unit aerosol optical depth), our findings $\left(60 \mathrm{~W} \mathrm{~m}^{-2}\right.$ ) are smaller than those of Rémy et al. (2015) and Stanelle et al. (2010), but this is once 


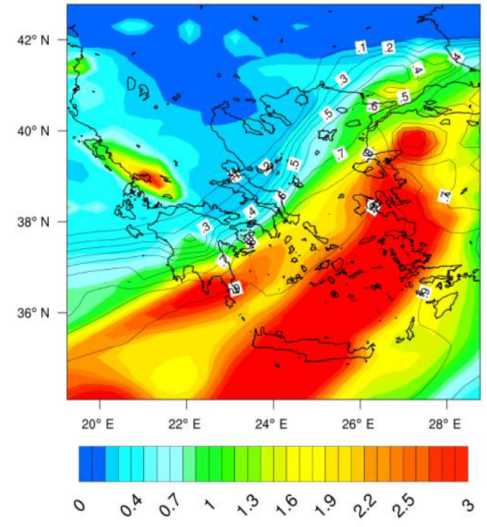

(a)

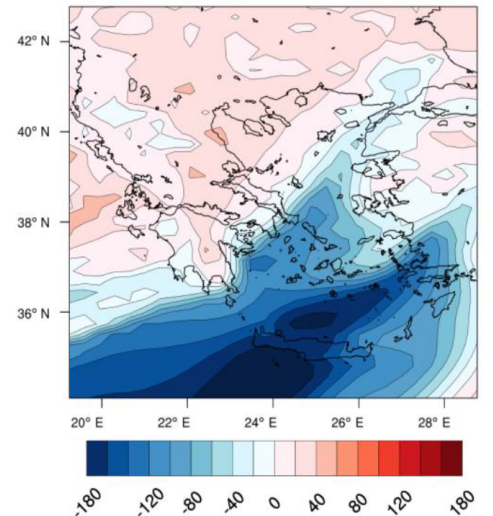

(b)

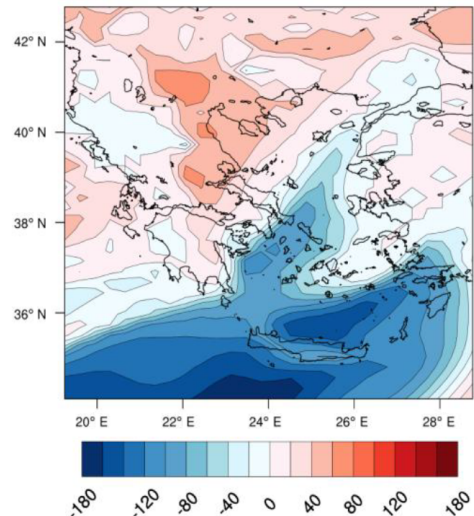

(c)

Figure 11. The spatial distribution of the (a) total AOD (at $550 \mathrm{~nm}$ ). Isolines indicate the dust fraction of the total AOD model values. The map corresponds to 12:00 UTC, when maximum AOD $\approx 5.2$. (b) Dust plume effect on GHI and (c) DNI (in W m ${ }^{-2}$ ) at the surface, averaged for the daytime hours of the extreme dust event of 1 February 2015 over Greece as predicted by COSMO-ART.
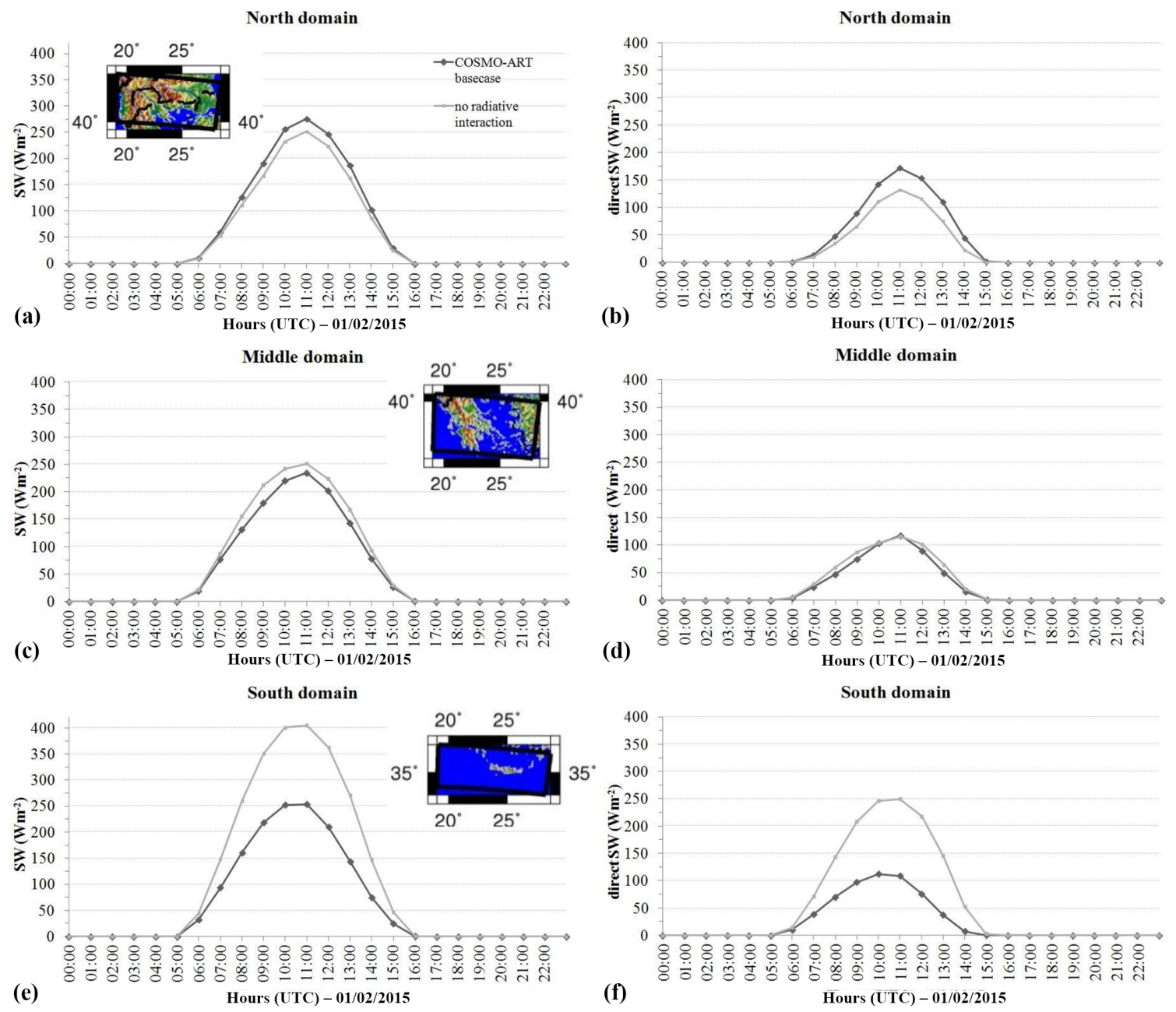

Figure 12. The diurnal variation of the GHI $(\mathbf{a}, \mathbf{c}, \mathbf{e})$ and DNI $(\mathbf{b}, \mathbf{d}, \mathbf{f})$ shortwave radiation zonally averaged over the northern, middle and southern domains (maps shown). The dark grey line corresponds to the base-case COSMO-ART run that includes aerosol-meteorology. The light grey line corresponds to the scenario when aerosol-meteorology interaction is switched off. 
more expected, as their findings correspond to hourly (noon) values $\left(-140\right.$ to $\left.-150 \mathrm{~W} \mathrm{~m}^{-2}\right)$ experienced over Africa.

Surprisingly, further inland in the Balkan peninsula, where the surface is less affected by the dust plume directly (AOD $<0.5$, dust fraction $<0.4$, Fig. 12a), increased amounts of DNI (Fig. 11c) are received during the dust event. This is related to an increase of the air temperature within the plume (from surface to $2.5 \mathrm{~km}$; not shown). This, in turn, creates a temperature gradient which leads to a secondary atmospheric circulation towards the south. This is why the dust plume tongue is found shifted towards the south when the aerosol-meteorology interaction is switched on (basecase run) compared to the scenario with no interaction (not shown). Conclusively, the interaction of dust particles with the atmosphere leads to a positive feedback on solar radiation in the area north of the plume. These implications seem important, as the increase in the GHI (and DNI) is found +40 $(+60) \mathrm{W} \mathrm{m}^{-2}$ over most of the positively affected area. Similar dust radiative effects on the thermal gradient of the atmosphere have been already discussed in Stanelle et al. (2010).

In order to further examine the spatial gradient of the dust effect on the shortwave radiation during the day, thus the hourly energy potential, the hourly zonal means are calculated and plotted (Fig. 12). The negative impact of the dust plume on the DNI, linked to great losses in solar energy potential for CSP systems, lasts from 06:00 to 15:00 UTC (1 February) and maximises at 11:00 UTC $\left(-150 \mathrm{~W} \mathrm{~m}^{-2}\right.$, average $-80 \mathrm{~W} \mathrm{~m}^{-2}$ for the southern part of the domain). This value corresponds to more than $90 \%$ losses of DNI due to the presence of the dust plume over the southern EM. The impact is limited for the rest of the area, ranging from $-30 \mathrm{Wm}^{-2}$ (maximum effect over the middle domain at 09:00 UTC) to $+25 \mathrm{~W} \mathrm{~m}^{-2}$ (maximum effect over the northern domain at 11:00 UTC). Nevertheless, percentage values are not negligible, e.g. reaching a dust impact on the DNI of $+30 \%$ at the northern part of the domain and at 11:00 UTC. The dust impact on the GHI is similar, but refers to greater absolute values (e.g. $-400 \mathrm{~W} \mathrm{~m}^{-2}$ from the base-case run over the southern domain at 10:00 and 11:00 UTC and $-150 \mathrm{~W} \mathrm{~m}^{-2}$ from the scenario which does not take into account the interactions between dust particles and radiation). The consequent percentage losses of the solar energy potential for the PV systems reach $60 \%$ (maximum fraction, southern domain).

\section{Summary and conclusions}

This study reconfirms and quantifies high dust aerosol load impact on surface solar radiation, regional and local meteorology, modelling approaches and consequent horizontal and vertical structures and related phenomena. Understanding and determining the range of this impact on attenuation of the surface solar radiation as well as providing timely and adequately accurate forecasts, has major application to emerging solar energy exploitation. We firstly mapped and studied the 3-D structure of a severe dust event occurring on 1 February 2015 via synergy of MODIS/Aqua and CALIOP/CALIPSO space-borne observations. The pure dust outflow yielded $\mathrm{AOD}_{550 \mathrm{~nm}}$ values higher than 3 in the plume centre of mass, while extinction coefficient values were consistently larger than $0.2 \mathrm{~km}^{-1}$ and as high as $10 \mathrm{~km}^{-1}$. Then RTM simulations were performed using MODIS, CAMS and AERONET aerosol data as input. We found GHI values near local noon and under the dust plume of the order of 250 and $70 \mathrm{~W} \mathrm{~m}^{-2}$ for DNI, while the simulated attenuation due to dust was on average $-50 \%$ for GHI and $-90 \%$ for DNI (below the dust plume), indicating the effective radiative influence of the dust particles during extreme dust cases. Under cloudless conditions aerosol plays a very important role. For example, the aerosol mean effect in Athens for AOD between 0.11 and 0.22 and for SZA $40^{\circ}$ are 5 and $17 \%$ for GHI and DNI respectively, while in the presence of dust (i.e. 1 February $2015, \mathrm{AOD}=1.71$ ) the mean aerosol effect is increased by an order of 37 and $80 \%$ for GHI and DNI. At larger SZAs (e.g. $60^{\circ}$ ) this effect can reach values greater than $90 \%$. The CAMS provides AOD forecasts which enable forecasting solar energy and the aerosol impact. In this line, we highlighted the usefulness and accuracy (10\% compared to MODIS) of this aerosol forecast data stream. Using COSMO-ART we were able to quantify the important radiative impact of the dust plume over the EM (maximum daily value of the global radiative cooling over Crete is found $200 \mathrm{~W} \mathrm{~m}^{-2}$ ) and the respective mean energy losses for PV and CSP installations, which are consistent with the RTM simulations $(\approx 40 \%$ and $80 \%$ for GHI and DNI respectively). Since satellite-based observations and modelling results become more easily accessible from year to year, their synergy is promising for nowcasting, forecasting or analysing past aerosol events, at spatial resolutions that surface-based measurements cannot achieve. The synergistic use of satellite, ground-based measurements and multi-faceted modelling techniques (RTM, CTM and CAMS) in this study demonstrates the efficiency of such an approach in capturing the impact of dust storms (and expanding it to other similar aerosol plumes) on SSR and of increasing our understanding of the earth's radiation budget.

Data availability. All the data used and produced for the purposes of this paper are freely available and can be requested from the corresponding author. 
Appendix: Nomenclature and abbreviations

\begin{tabular}{|c|c|}
\hline AERONET & AErosol RObotic NETwork \\
\hline $\mathrm{AF}$ & Actinic flux \\
\hline AOD & Aerosol optical depth \\
\hline ART & Aerosol and reactive trace gases \\
\hline CAPIOL & $\begin{array}{l}\text { Cloud-Aerosol Lidar with Orthogonal } \\
\text { Polarization }\end{array}$ \\
\hline CALIPSO & $\begin{array}{lll}\text { Cloud-Aerosol } & \text { Lidar } & \text { and } \\
\text { Infrared Pathfinder } & \text { Satellite } & \text { Ob- } \\
\text { servations } & & \end{array}$ \\
\hline CAMS & $\begin{array}{l}\text { Copernicus Atmosphere Monitoring } \\
\text { Service }\end{array}$ \\
\hline $\mathrm{CF}$ & Cloud fraction \\
\hline CSP & Concentrated solar power \\
\hline CTM & Chemical transport model \\
\hline C6 & Collection 6 \\
\hline DB & Deep Blue \\
\hline DNI & Direct Normal Irradiance \\
\hline DT & Dark Target \\
\hline EARLINET & European Aerosol Lidar Network \\
\hline ECMWF & $\begin{array}{l}\text { European Centre for Medium-Range } \\
\text { Weather Forecasts }\end{array}$ \\
\hline EDGAR & $\begin{array}{l}\text { Emission Database for Global Atmo- } \\
\text { spheric Research }\end{array}$ \\
\hline EM & Eastern Mediterranean \\
\hline FNL & Final analysis data \\
\hline GAW & Global Atmosphere Watch \\
\hline GHI & Global Horizontal Irradiance \\
\hline GOCART & $\begin{array}{l}\text { Goddard Chemistry Aerosol Radiation } \\
\text { and Transport }\end{array}$ \\
\hline libRadtran & library for Radiative transfer \\
\hline MACC & $\begin{array}{l}\text { Monitoring Atmospheric Composition } \\
\text { and Climate }\end{array}$ \\
\hline MAPSS & $\begin{array}{l}\text { Multi-sensor Aerosol Products Sam- } \\
\text { pling System }\end{array}$ \\
\hline MODIS & $\begin{array}{l}\text { Moderate Resolution Imaging Spectro- } \\
\text { radiometer }\end{array}$ \\
\hline NCEP & $\begin{array}{l}\text { National Centers for Environmental } \\
\text { Protection }\end{array}$ \\
\hline PV & Photovoltaics \\
\hline RTM & Radiative transfer model \\
\hline SSR & Surface solar radiation \\
\hline SPEW & Speciated Particulate Emission Wizard \\
\hline SSA & Single-scattering albedo \\
\hline SW & Shortwave \\
\hline SZA & Solar zenith angle \\
\hline TOA & Top of atmosphere \\
\hline UV & Ultraviolet \\
\hline VIS & Visible \\
\hline
\end{tabular}


Competing interests. The authors declare that they have no conflict of interest.

Special issue statement. This article is part of the special issue "SKYNET - the international network for aerosol, clouds, and solar radiation studies and their applications". It does not belong to a conference.

Acknowledgements. This research has been partly funded by the H2020 GEO-CRADLE project under grant agreement No 690133. We also acknowledge ACTRIS-2, which has received funding from EU H2020 research and innovation programme (grant agreement No 654109). The computational time spent for the COSMO-ART simulations is granted from the Greek Research \& Technology Network (GRNET) in the National HPC facility - ARIS.

Edited by: Omar Torres

Reviewed by: two anonymous referees

\section{References}

Allen, R. J., Norris, J. R., and Wild, M.: Evaluation of multidecadal variability in CMIP5 surface solar radiation and inferred underestimation of aerosol direct effects over Europe, China, Japan, and India, J. Geophys. Res.-Atmos., 118, 6311-6336, https://doi.org/10.1002/jgrd.50426, 2013.

Amiridis, V., Kafatos, M., Perez, C., Kazadzis, S., Gerasopoulos, E., Mamouri, R. E., and Zerefos, C.: The potential of the synergistic use of passive and active remote sensing measurements for the validation of a regional dust model, Ann. Geophys., 27, 31553164, 2009.

Amiridis, V., Marinou, E., Tsekeri, A., Wandinger, U., Schwarz, A., Giannakaki, E., and Ansmann, A.: LIVAS: a 3-D multiwavelength aerosol/cloud database based on CALIPSO and EARLINET, Atmos. Chem. Phys., 15, 7127-7153, https://doi.org/10.5194/acp-15-7127-2015, 2015.

Athanasopoulou, E., Rieger, D., Walter, C., Vogel., H., Karali, A., Hatzaki, M., and Roussos, A.: Fire risk, atmospheric chemistry and radiative forcing assessment of wildfires in eastern Mediterranean, Atmos. Environ., 95, 113-125, 2014.

Athanasopoulou, E., Protonotariou, A., Papangelis, G., Tombrou, M., Mihalopoulos, N., and Gerasopoulos, E.: Long-range transport of Saharan dust and chemical transformations over the Eastern Mediterranean, Atmos. Environ., 140, 592-604, 2016.

Baldauf, M., Seifert, A., Förstner, J., Majewski, D., Raschendorfer, M., and Reinhardt, T.: Operational convective-scale numerical weather prediction with the COSMO model: description and sensitivities, Mon. Weather Rev., 139, 3887-3905, https://doi.org/10.1175/MWR-D-10-05013.1, 2011.

Bangert, M., Kottmeier, C., Vogel, B., and Vogel, H.: Regional scale effects of the aerosol cloud interaction simulated with an online coupled comprehensive chemistry model, Atmos. Chem. Phys., 11, 4411-4423, https://doi.org/10.5194/acp-114411-2011, 2011.
Bangert, M., Nenes, A., Vogel, B., Vogel, H., Barahona, D., Karydis, V. A., Kumar, P., Kottmeier, C., and Blahak, U.: Saharan dust event impacts on cloud formation and radiation over Western Europe, Atmos. Chem. Phys., 12, 4045-4063, https://doi.org/10.5194/acp-12-4045-2012, 2012.

Benedetti, A., Morcrette, J. J., Boucher, O., Dethof, A., and the GEMS-AER team: Aerosol analysis and forecast in the ECMWF Integrated Forecast System. Part II: Data assimilation, J. Geophys. Res., 114, D13205, https://doi.org/10.1029/2008JD011115, 2009.

Boucher, O., Pham, M., and Venkataraman, C.: Simulation of the atmospheric sulfur cycle in the LMD GCM: model description, model evaluation, and global and European budgets, Note 23, Inst. Pierre-Simon Laplace, Paris, France, 26 pp., 2002.

Cahalan, R., Oreopoulos, L., Marshak, A., Evans, F., Davis, A., and Zhuravleva, T. B.: The I3RC: bringing together the most advanced radiative transfer tools for cloudy atmospheres, B. Am. Meteorol. Soc., 86, 9, 1275-1293, 2005.

Charabi, Y. and Gastli, A. Spatio-temporal assessment of dust risk maps for solar energy systems using proxy data, Renew. Energ., 44, 23-31, 2012.

Claquin, T., Schulz, M., Balkanski, Y. M., and Boucher, O.: Uncertainties in assessing radiative forcing by mineral dust, Tellus B, 50, 491-505, 1998.

Dahlback, A. and Stamnes, K. A.: New spherical model for computing the radiation field available for photolysis and heating at twilight, Planet. Space Sci., 39, 671-83, 1991.

Dee, D. P. and Uppala, S.: Variational bias correction of satellite radiance data in the ERA-Interim reanalysis, Q. J. Roy. Meteor Soc., 135, 1830-1841, https://doi.org/10.1002/qj.493, 2009.

Dentener, F., Kinne, S., Bond, T., Boucher, O., Cofala, J., Generoso, S., Ginoux, P., Gong, S., Hoelzemann, J. J., Ito, A., Marelli, L., Penner, J. E., Putaud, J.-P., Textor, C., Schulz, M., van der Werf, G. R., and Wilson, J.: Emissions of primary aerosol and precursor gases in the years 2000 and 1750 prescribed data-sets for AeroCom, Atmos. Chem. Phys., 6, 43214344, https://doi.org/10.5194/acp-6-4321-2006, 2006.

Diaz, J. P., Exposito, F. J., Torres, J., Herrera, F., Prospero, J. M., and Romero, M. C.: Radiative properties of aerosols in Saharan dust outbreaks using ground-based and satellite data: applications to radiative forcing, J. Geophys. Res., 106, 18403-18416, 2001.

Dirnberger, D., Blackburn, G., Müller, B., and Reise, C.: On the impact of solar spectral irradiance on the yield of different PV technologies, Sol. Energ. Mat. Sol. C., 132, 431-442, 2015.

Dubovik, O., Smirnov, A., Holben, B. N., King, M. D., Kaufman, Y. J., Eck, T. F., and Slutsker, I.: Accuracy assessments of aerosol optical properties retrieved from Aerosol Robotic Network (AERONET) Sun and sky radiance measurements, J. Geophys. Res.-Atmos., 105, 9791-9806, 2000.

Dubovik, O., Holben, B., Eck, T. F., Smirnov, A., Kaufman, Y. J., King, M. D., and Slutsker, I.: Variability of absorption and optical properties of key aerosol types observed in worldwide locations, J. Atmos. Sci., 59, 590-608, 2002.

Emde, C., Buras-Schnell, R., Kylling, A., Mayer, B., Gasteiger, J., Hamann, U., Kylling, J., Richter, B., Pause, C., Dowling, T., and Bugliaro, L.: The libRadtran software package for radiative transfer calculations (version 2.0.1), Geosci. Model Dev., 9, 1647-1672, https://doi.org/10.5194/gmd-9-1647-2016, 2016. 
Emde, C. and Mayer, B.: Simulation of solar radiation during a total eclipse: a challenge for radiative transfer, Atmos. Chem. Phys., 7, 2259-2270, https://doi.org/10.5194/acp-7-2259-2007, 2007.

Flaounas, E., Kotroni, V., Lagouvardos, K., Kazadzis, S., Gkikas, A., and Hatzianastassiou, N.: Cyclone contribution to dust transport over the Mediterranean region, Atmos. Sci. Lett., 16, 473-478, 2015.

Georgoulias, A. K., Alexandri, G., Kourtidis, K. A., Lelieveld, J., Zanis, P., and Amiridis, V.: Differences between the MODIS Collection 6 and 5.1 aerosol datasets over the greater Mediterranean region, Atmos. Environ., 147, 310-319, https://doi.org/10.1016/j.atmosenv.2016.10.014, 2016.

Gerasopoulos, E., Koulouri, E., Kalivitis, N., Kouvarakis, G., Saarikoski, S., Mäkelä, T., Hillamo, R., and Mihalopoulos, N.: Size-segregated mass distributions of aerosols over Eastern Mediterranean: seasonal variability and comparison with AERONET columnar size-distributions, Atmos. Chem. Phys., 7, 2551-2561, https://doi.org/10.5194/acp-7-2551-2007, 2007.

Gerasopoulos, E., Amiridis, V., Kazadzis, S., Kokkalis, P., Eleftheratos, K., Andreae, M. O., Andreae, T. W., El-Askary, H., and Zerefos, C. S.: Three-year ground based measurements of aerosol optical depth over the Eastern Mediterranean: the urban environment of Athens, Atmos. Chem. Phys., 11, 2145-2159, https://doi.org/10.5194/acp-11-2145-2011, 2011.

Gkikas, A., Houssos, E. E., Hatzianastassiou, N., Papadimas, C. D., and Bartzokas, A.: Synoptic conditions favouring the occurrence of aerosol episodes over the broader Mediterranean basin, Q. J. Roy. Meteor. Soc., 138, 932-949, 2012.

Gkikas, A., Hatzianastassiou, N., Mihalopoulos, N., Katsoulis, V., Kazadzis, S., Pey, J., Querol, X., and Torres, O.: The regime of intense desert dust episodes in the Mediterranean based on contemporary satellite observations and ground measurements, Atmos. Chem. Phys., 13, 12135-12154, https://doi.org/10.5194/acp-13-12135-2013, 2013.

Gkikas, A., Basart, S., Hatzianastassiou, N., Marinou, E., Amiridis, V., Kazadzis, S., Pey, J., Querol, X., Jorba, O., Gassó, S., and Baldasano, J. M.: Mediterranean intense desert dust outbreaks and their vertical structure based on remote sensing data, Atmos. Chem. Phys., 16, 8609-8642, https://doi.org/10.5194/acp-16-8609-2016, 2016.

Grandey, B. S., Stier, P., and Wagner, T. M.: Investigating relationships between aerosol optical depth and cloud fraction using satellite, aerosol reanalysis and general circulation model data, Atmos. Chem. Phys., 13, 3177-3184, https://doi.org/10.5194/acp-13-3177-2013, 2013.

Guelle, W., Schulz, M., Balkanski, Y., and Dentener, F.: Influence of the source formulation on modeling the atmospheric global distribution of the sea salt aerosol, J. Geophys. Res., 106, 27509 27524, 2001.

Haywood, J. M., Francis, P. N., Glew, M. D., and Taylor, J. P.: Optical properties and direct radiative effect of Saharan dust: a case study of two Saharan dust outbreaks using aircraft data, J. Geophys. Res., 106, 18417-18430, 2001.

Hess, M., Koepke, P., and Schult, I.: Optical properties of aerosols and clouds: the software package OPAC, B. Am. Soc., 79, 831844,1998

Holben, B. N., Eck, T. F., Slutsker, I., Tanre, D., Buis, J. P., Setzer, A., and Lavenu, F.: AERONET - a federated instrument net- work and data archive for aerosol characterization, Remote Sens. Environ., 66, 1-16, 1998.

Holben, B. N., Tanre, D., Smirnov, A., Eck, T. F., Slutsker, I., Abuhassan, N., and Kaufman, Y. J.: An emerging ground-based aerosol climatology: aerosol optical depth from AERONET, J. Geophys. Res.-Atmos., 106, 12067-12097, 2001.

Intergovernmental Panel on Climate Change (IPCC): Climate Change 2013, The Physical Science Basis, Contribution of the Working Group I to the Fifth Assessment Report of the IPCC, Cambridge University Press, New York, 2013.

Ishii, T., Otani, K., Takashima, T., and Xue, Y.: Solar spectral influence on the performance of photovoltaic (PV) modules under fine weather and cloudy weather conditions, Prog. Photovoltaics, 21, 481-489, 2013.

Kalivitis, N., Gerasopoulos, E., Vrekoussis, M., Kouvarakis, G., Kubilay, N., Hatzianastassiou, N., Vardavas, I., and Mihalopoulos, N.: Dust transport over the eastern Mediterranean derived from Total Ozone Mapping Spectrometer, Aerosol Robotic Network, and surface measurements, J. Geophys. Res., 112, D03202, https://doi.org/10.1029/2006JD007510, 2007.

Kato, S., Ackerman, T., Mather, J., and Clothiaux, E.: The $k$ distribution method and correlated- $k$ approxiamation for shortwave radiative transfer model, J. Quant Spectrosc. Ra., 62, 109$121,1999$.

Kaufman, Y. J., Karnieli, A., and Tanre, D.: Detection of dust over the desert by EOS-MODIS, IEEE T. Geosci. Remote, 38, 525531, 2000.

Kaufman, Y. J., Tanre, D., Dubovic, O., Karnieli, A., and Remer, L. A.: Absorption of sunlight by dust as inferred from satellite and ground-based remote sensing, Geophys. Res. Lett., 28, 1479-1482, 2001.

Kinne, S. and Pueschel, R.: Aerosol radiative forcing for Asian continental outflow, Atmos. Environ., 35, 5019-5028, 2001.

Kinne, S., Lohmann, U., Feichter, J., Schulz, M., Timmreck, C., Ghan, S., and Tegen, I.: Monthly averages of aerosol properties: a global comparison among models, satellite data, and AERONET ground data, J. Geophys. Res.-Atmos., 108, 4634, https://doi.org/10.1029/2001JD001253, 2003.

Kosmopoulos, P. G., Kaskaoutis, D. G., Nastos, P. T., and Kambezidis, H. D.: Seasonal variation of columnar aerosol optical properties over Athens, Greece, based on MODIS data, Remote Sens. Environ., 112, 2354-2366, 2008.

Kosmopoulos, P. G., Kaskaoutis, D. G., Prasad, A. K., Sinha, P. R., and Rashki, A. R.: Spatial and vertical distribution of Sahara dust event over eastern Mediterranean in winter using remote sensing observations, 6th International Workshop on Sand/Duststorms and Associated Dustfall, Athens, Greece, 7-9 September 2001, 2011.

Kosmopoulos, P. G., Kazadzis, S., Flocas, H. A., Marinou, E., Amiridis, V., Taylor, M., and Jacovidis, C. P.: A 3D aerosol climatology in the atmosphere of Greece by remote sensing and radiative transfer modeling techniques, in: Proceedings of the 12th International Conference on Meteorology, Climatology and Atmospheric Physics, Vol. 2, 13-17, ISBN: 978-960-524-430-9, 2014.

Kosmopoulos, P. G., Kazadzis, S., Lagouvardos, K., Kotroni, V., and Bais, A.: Solar energy prediction and verification using operational model forecasts and ground-based solar measurements, Energy, 93, 1918-1930, 2015. 
Kosmopoulos, P. G., Kazadzis, S., Taylor, M., Bais, A., Lagouvardos, K., Kotroni, V., Keramitsoglou, I., and Kiranoudis, C.: Estimation of the solar energy potential in Greece using satellite and ground-based observations, in: Perspectives on Atmospheric Sciences, 1149-1156, Springer Atmospheric Sciences, Springer, Cham, 2017.

Kuenen, J. J. P., Visschedijk, A. J. H., Jozwicka, M., and Denier van der Gon, H. A. C.: TNO-MACC_II emission inventory; a multi-year (2003-2009) consistent high-resolution European emission inventory for air quality modelling, Atmos. Chem. Phys., 14, 10963-10976, https://doi.org/10.5194/acp-14-109632014, 2014.

Langerock, B., De Mazière, M., Hendrick, F., Vigouroux, C., Desmet, F., Dils, B., and Niemeijer, S.: Description of algorithms for co-locating and comparing gridded model data with remote-sensing observations, Geosci. Model Dev., 8, 911-921, https://doi.org/10.5194/gmd-8-911-2015, 2015.

Levy, R. C., Mattoo, S., Munchak, L. A., Remer, L. A., Sayer, A. M., Patadia, F., and Hsu, N. C.: The collection 6 MODIS aerosol products over land and ocean, Atmos. Meas. Tech., 6, 2989-3034, https://doi.org/10.5194/amt-6-2989-2013, 2013.

Li, F., Vogelmann, A. M., and Ramanathan, V.: Saharan dust aerosol radiative forcing measured from space, J. Climate, 17, 25582571, 2004.

Lindfors, A. V., Kouremeti, N., Arola, A., Kazadzis, S., Bais, A. F., and Laaksonen, A.: Effective aerosol optical depth from pyranometer measurements of surface solar radiation (global radiation) at Thessaloniki, Greece, Atmos. Chem. Phys., 13, 37333741, https://doi.org/10.5194/acp-13-3733-2013, 2013.

MACC near-real time global atmospheric composition service (Validation report): System evolution and performance statistics (Status up to 1 March 2015), MACC-III Deliverable D37.6, 2015, File: MACCIII_VAL_DEL_D_37.6_NRTReport04_20150528, 2015.

Mamouri, R.-E., Ansmann, A., Nisantzi, A., Solomos, S., Kallos, G., and Hadjimitsis, D. G.: Extreme dust storm over the eastern Mediterranean in September 2015: satellite, lidar, and surface observations in the Cyprus region, Atmos. Chem. Phys., 16, 13711-13724, https://doi.org/10.5194/acp-16-13711-2016, 2016.

Marquart, S. and Mayer, B.: Towards a reliable GCM estimation of contrail radiative forcing, Geophys. Res. Lett., 29, 1179, https://doi.org/10.1029/2001GL014075, 2002.

Mayer, B. and Kylling, A.: Technical note: The libRadtran software package for radiative transfer calculations - description and examples of use, Atmos. Chem. Phys., 5, 1855-1877, https://doi.org/10.5194/acp-5-1855-2005, 2005.

Miller, R. L., Tegen, I., and Perlwitz, J.: Surface radiative forcing by soil dust aerosols and the hydrologic cycle, J. Geophys. Res., 109, D04203, https://doi.org/10.1029/2003JD004085, 2004.

Morcrette, J.-J., Beljaars, A., Benedetti, A., Jones, L., and Boucher, O.: Sea-salt and dust aerosols in the ECMWF IFS model, Geophys. Res. Lett., 35, L24813, https://doi.org/10.1029/2008GL036041, 2008.

Morcrette, J.-J., Boucher, O., Jones, L., Salmond, D., Bechtold, P., and Untch, A.: Aerosol analysis and forecast in the ECMWF Integrated Forecast System. Part I: Forward modelling, J. Geophys.
Res., 114D, D06206, https://doi.org/10.1029/2008JD011235, 2009.

NCEP/National Weather Service/NOAA/U.S. Department of Commerce 2000, updated daily: NCEP FNL Operational Model Global Tropospheric Analyses, continuing from July 1999, Research Data Archive at the National Center for Atmospheric Research, Computational and Information Systems Laboratory, available at: https://rda.ucar.edu/datasets/ds083.2/ (last access: January 2017), 2000.

Nyamsi, W., Espinar, B., Blanc, P., Wand ald, L.: How close to detailed spectral calculations is the $k$-distribution method and correlated- $k$ approximation of Kato et al. (1999) in each spectral interval? Meteorol. Z., 23, 547-556, 2014.

Omar, A., Winker, D., Kittaka, C., Vaughan, M., Liu, Z., Hu, Y. X., Trepte, C., Rogers, R., Ferrare, R., Lee, K., Kuehn, R., and Hostetler, C.: The CALIPSO automated aerosol classification and lidar ratio selection algorithm, J. Atmos. Ocean. Tech., 26, 1994-2014, https://doi.org/10.1175/2009jtecha1231.1, 2009.

Omar, A., Tackett, J., Magill, B. Vaughan, M., Kar, J., Winker, D., and Trepte, C.: Enhancements to the CALIOP aerosol subtyping and lidar ratio selection algorithms for Level II version 4, CALIPSO/CloudSat 2016 Science Team Meeting, Newport News, Virginia, 1-3 Mar 2016, available at: https://www-calipso.larc.nasa.gov/resources/calipso_users_ guide/qs/qs_lid_12_all_v4-10_files/2OmarSubtypingPoster.pdf, http://stm.dpc.cira.colostate.edu/, 2016.

Pandithurai, G., Dipu, S., Dani, K. K., Tiwari, S., and Pinker, R. T.: Aerosol radiative forcing during dust events over New Delhi, India, J. Geophys. Res., 113, D13209, https://doi.org/10.1029/2008JD009804, 2008.

Papadimas, C. D., Hatzianastassiou, N., Matsoukas, C., Kanakidou, M., Mihalopoulos, N., and Vardavas, I.: The direct effect of aerosols on solar radiation over the broader Mediterranean basin, Atmos. Chem. Phys., 12, 7165-7185, https://doi.org/10.5194/acp-12-7165-2012, 2012.

Papayannis, A., Balis, D., Amiridis, V., Chourdakis, G., Tsaknakis, G., Zerefos, C., Castanho, A. D. A., Nickovic, S., Kazadzis, S., and Grabowski, J.: Measurements of Saharan dust aerosols over the Eastern Mediterranean using elastic backscatter-Raman lidar, spectrophotometric and satellite observations in the frame of the EARLINET project, Atmos. Chem. Phys., 5, 2065-2079, https://doi.org/10.5194/acp-5-2065-2005, 2005.

Petrenko, M., Ichoku, C., and Leptoukh, G.: Multi-sensor Aerosol Products Sampling System (MAPSS), Atmos. Meas. Tech., 5, 913-926, https://doi.org/10.5194/amt-5-913-2012, 2012.

Platnick, S., Meyer, K. G., King, M. D., Wind, G., Amarasinghe, N., Marant, B., and Yang, P.: The MODIS cloud optical and microphysical products: collection 6 updates and examples from terra and aqua, IEEE T. Geosci. Remote, 55, 502-525, https://doi.org/10.1109/TGRS.2016.2610522, 2016.

Qian, Y., Wang, W., Leung, L. R., and Kaiser, D. P.: Variability of solar radiation under cloud-free skies in China: the role of aerosols, Geophys. Res. Lett., 34, https://doi.org/10.1029/2006GL028800, 2007.

Reddy, M. S., Boucher, O., Bellouin, N., Schulz, M., Balkanski, Y., Dufresne, J.-L., and Pham, M.: Estimates of global multi-component aerosol optical depth and direct radiative perturbation in the Laboratoire de Météorologie Dynamique 
general circulation model, J. Geophys. Res., 110, D10S16, https://doi.org/10.1029/2004JD004757, 2005.

Rémy, S., Benedetti, A., Bozzo, A., Haiden, T., Jones, L., Razinger, M., Flemming, J., Engelen, R. J., Peuch, V. H., and Thepaut, J. N.: Feedbacks of dust and boundary layer meteorology during a dust storm in the eastern Mediterranean, Atmos. Chem. Phys., 15, 12909-12933, https://doi.org/10.5194/acp-1512909-2015, 2015.

Rieger, D., Bangert, M., Kottmeier, C., Vogel, H., and Vogel, B.: Impact of aerosol on post-frontal convective clouds over Germany, Tellus B, 66, 22528, https://doi.org/10.3402/tellusb.v66.22528, 2014.

Rockel, B., Will, A., and Hense, A.: The regional climate model COSMO-CLM (CCLM), Meteorol. Z., 17, 347-348, https://doi.org/10.1127/0941-2948/2008/0309, 2008.

Ruiz-Arias, J. A., Gueymard, C. A., Santos-Alamillos, F. J., and Poza-Vazquez, D.: Worldwide impact of aerosol's time scale on the predicted long-term concentrating solar power potential, Nature, Scientific Reports, 6, 30546, https://doi.org/10.1038/srep30546, 2016.

Salomonson, V. V., Barnes, W. L., Maymon, P. W., Montgomery, H. E., and Ostrow, H.: MODIS: advanced facility instrument for studies of the Earth as a system, IEEE T. Geosci. Remote, 27, 145-153, https://doi.org/10.1109/36.20292, 1989.

Sayer, A. M., Hsu, N. C., Bettenhausen, C., Jeong, M., Meister, G., and $\mathrm{Al}, \mathrm{S}$. E. T.: Effect of MODIS terra radiometric calibration improvements on collection 6 deep blue aerosol products: validation and terra/aqua consistency, J. Geophys. Res.-Atmos., 120, 12157e12174, https://doi.org/10.1002/2015JD023878, 2015.

Schulz, M., de Leeuw, G., and Balkanski, Y.: Sea-salt aerosol source functions and emissions, in: Emission of Atmospheric Trace Compounds, edited by: Granier, C., Artaxo, P., and Reeves, C. E., Kluwer Acad., Norwell, Mass, 333-354, 2004.

Schwartz, S. E., Charlson, R. J., Kahn, R., and Rodhe, H.: Earth's climate sensitivity: apparent in consistencies in recent assessments, Earths Future, 2, 601-5, 2014.

Shettl, E. E. P.: Models of aerosols, clouds and precipitation for atmospheric propagation studies, in: Proceedings of AGARD conference 454 on atmospheric propagation in the UV, visible, IR and MM-region and related system aspects, Copenhagen, Denmark, 9-13 October 1989.

Smirnov, A., Holben, B. N., Eck, T. F., Dubovik, O., and Slutsker, I.: Cloud screening and quality control algorithms for the AERONET data base, Remote Sens. Environ., 73, 337-349, 2000.

Stanelle, T., Vogel, B., Vogel, H., Bäumer, D., and Kottmeier, C.: Feedback between dust particles and atmospheric processes over West Africa during dust episodes in March 2006 and June 2007, Atmos. Chem. Phys., 10, 10771-10788, https://doi.org/10.5194/acp-10-10771-2010, 2010.

Stein, A. F., Draxler, R. R., Rolph, G. D., Stunder, B. J. B., Cohen, M. D., and Ngan, F.: NOAA's HYSPLIT atmospheric transport and dispersion modeling system, B. Am. Meteorol. Soc., 96, 2059-2077, 2015.
Taylor, M., Kazadzis, S., and Gerasopoulos, E.: Multi-modal analysis of aerosol robotic network size distributions for remote sensing applications: dominant aerosol type cases, Atmos. Meas. Tech., 7, 839-858, https://doi.org/10.5194/amt-7839-2014, 2014.

Taylor, M., Kazadzis, S., Amiridis, V., and Kahn, R. A.: Global aerosol mixtures and their multiyear and seasonal characteristics, Atmos. Environ., 116, 112-129, https://doi.org/10.1016/j.atmosenv.2015.06.029, 2015.

Tegen, I., Lacis, A. A., and Fung, I.: The influence of climate forcing of mineral aerosols from disturbed soils, Nature, 4, 380, 6573, 419-422, 1996.

Tesche, M., Ansmann, A., Müller, D., Althausen, D., Engelmann, R., Freudenthaler, V., and Groß, S.: Vertically resolved separation of dust and smoke over Cape Verde using multiwavelength Raman and polarization lidars during Saharan Mineral Dust Experiment 2008, J. Geophys. Res.-Atmos., 114, D13202, https://doi.org/10.1029/2009JD011862, 2009.

Turnock, S. T., Spracklen, D. V., Carslaw, K. S., Mann, G. W., Woodhouse, M. T., Forster, P. M., Haywood, J., Johnson, C. E., Dalvi, M., Bellouin, N., and Sanchez-Lorenzo, A.: Modelled and observed changes in aerosols and surface solar radiation over Europe between 1960 and 2009, Atmos. Chem. Phys., 15, $9477-$ 9500, https://doi.org/10.5194/acp-15-9477-2015, 2015.

Vaughan, M. A., Powell, K. A., Kuehn, R. E., Young, S. A., Winker, D. M., and Getzewich, B. J.: Fully automated detection of cloud and aerosol layers in the CALIPSO lidar measurements, J. Atmos. Ocean. Tech., 26, 2034-2050, 2009.

Vogel, B., Vogel, H., Bäumer, D., Bangert, M., Lundgren, K., Rinke, R., and Stanelle, T.: The comprehensive model system COSMO-ART - Radiative impact of aerosol on the state of the atmosphere on the regional scale, Atmos. Chem. Phys., 9, 86618680, https://doi.org/10.5194/acp-9-8661-2009, 2009.

Vogel, B., Hoose, C., Vogel, H., and Kottmeier, C.: A model of dust transport applied to the Dead Sea Area, Meteorol. Z. 15, 611624, 2006.

Vrekoussis, M., Richter, A., Hilboll, A., Burrows, J. P., and Mihalopoulos, N.: Economic crisis detected from space: air quality observations over Athens/Greece, Geoph. Res. Lett., 40, 1-6, https://doi.org/10.1002/grl.50118, 2013.

Winker, D. M., Vaughan, M. A., Omar, A. H., Hu, Y., Powell, K. A., Liu, Z., Hunt, W. H., and Young, S. A.: Overview of the CALIPSO mission and CALIOP data processing algorithms, J. Atmos. Ocean. Tech., 26, 2310-2323, https://doi.org/10.1175/2009JTECHA1281.1, 2009.

Zängl, G., Reinert, D., Rípodas, P., and Baldauf, M.: The ICON (ICOsahedral Non-hydrostatic) modelling framework of DWD and MPI-M: description of the non-hydrostatic dynamical core, Q. J. Roy. Meteor. Soc., 141, 563-579, https://doi.org/10.1002/qj.2378, 2015. 